اثر كاربرد بيوجارهاى هسته خرما بر فعاليت آنزيمى در خاكهاى ريزوسفرى و غيرريزوسفرى كياه گل گاوزبان ارويايى

آسيه عباسيان' و محسن شكل آبادى

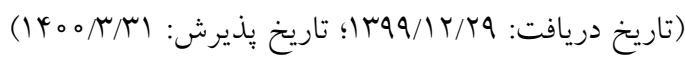

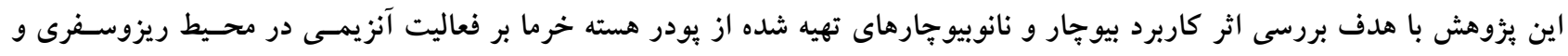

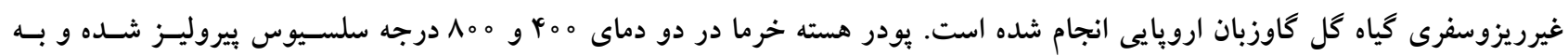

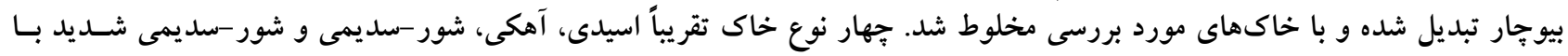

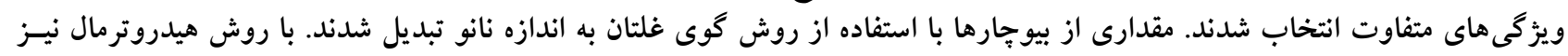

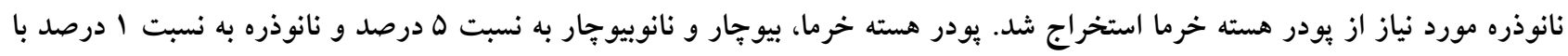

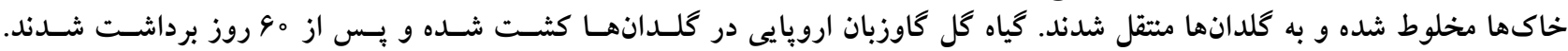

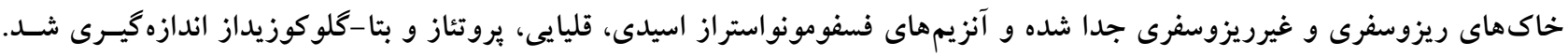

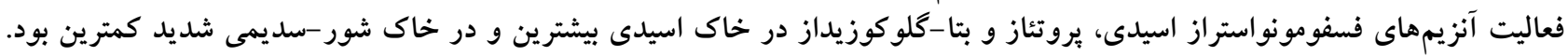

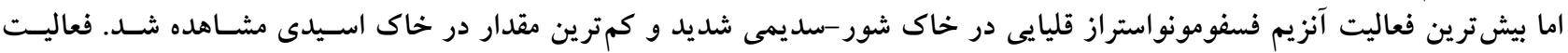

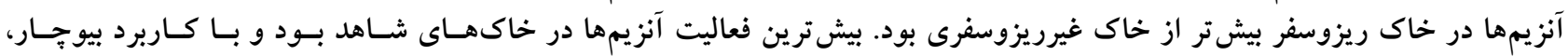

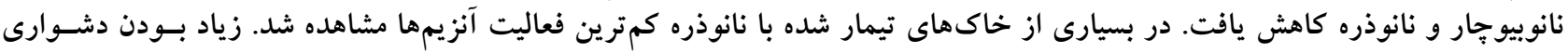

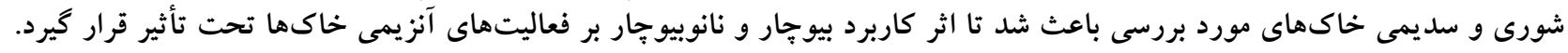

وازههاى كليدى: بيوجار، نانوبيوجار، نانوذره، خاك آهكى، خاك شور -سديمى، فعاليت آنزيمى

فيز يكى و شيميايى خاك كمك مى كند (TV). با افـزودن بيوجـار

مقدمه

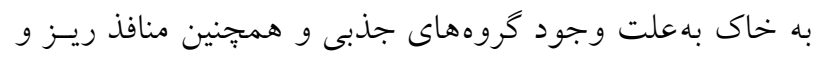
بيو جار يكى ماده متخلخل، غنى از كربن و ريزدانسه اسـت كـه از

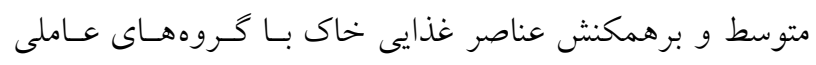

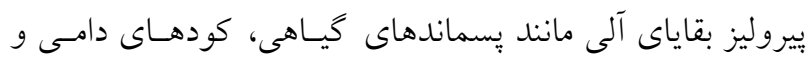

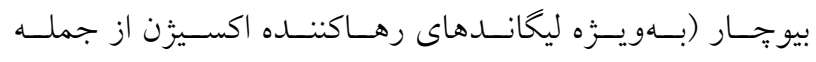

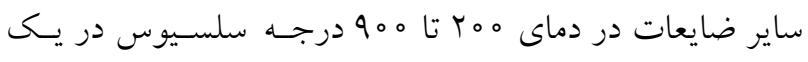

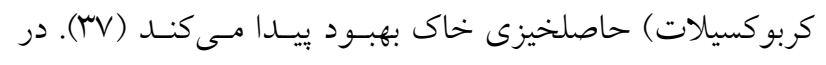

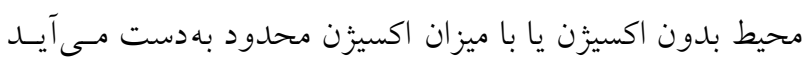

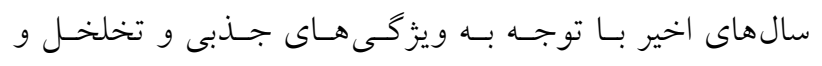

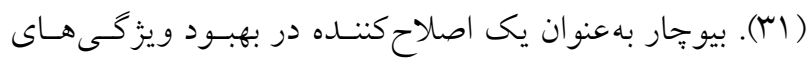
1- كروه خاكشناسى، دانشكده كشاورزى، دانشخاه بوعلى سينا

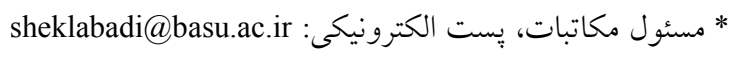


افزودن بيوجار به خاك، باعث تغيير معنى دار نسبت بـاكترى بـهـ قارج و جمعيت ميكروبى غالب خاك شده (N) و همحنين با اثر بر فعاليت آنزيمى و فعاليت ميكروبى مسىتوانــ موجـب تغييـر

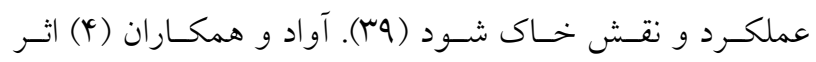
بيو جار را بر تجزيه بقاياى گياهى بررسى كـرده و دريافتـــ كـه كاربرد بيوجار فعاليت آنزيمى را در خاك شنى بيشتر از خـاك لومى افزايش مى دهد. يازفريرو و همكاران (Y9) افزايش فعاليت

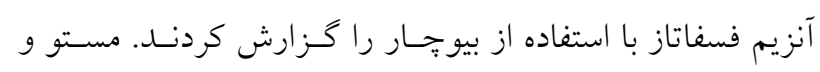

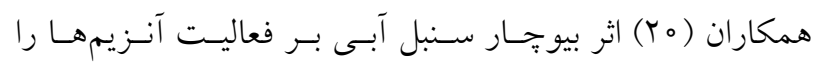

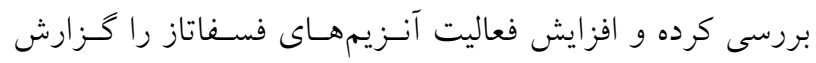

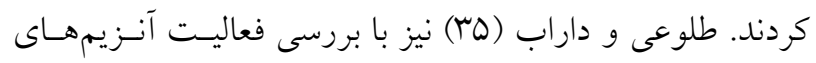
اورهآز و فسفاتازهاى اسـيدى و قليـايى در خـاك و بيوجــار در كشت كلدانى ذرت تحت تنش كــمآبـى، نشـان دادنــ فعاليـت فسفاتازهاى اسيدى و قليايى در خاك هاى تيمار شده با بيوجــار نسبت به خاكهاى بدون بيو جار افزايش يافت. اثـر بيوجــار بـر

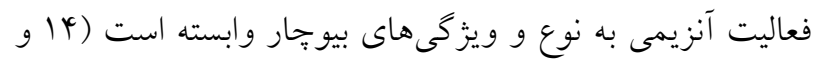

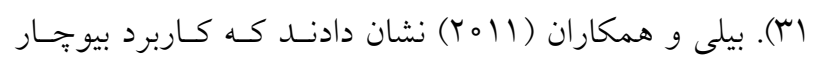
توليد شده از بقاياى گياه Panicum virgatum نسبت به بيو جـار جّوب، كربن محلول و عناصر غذايى بيشترى دارد و مسىتوانـد منجر به افزايش فعاليت آنزيمسى شـود (4). ميسرزوا هرسـتك و

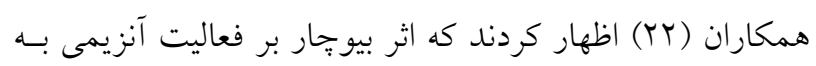
نسبت بيو جار مصرفى وابسته است و نسبتهاى كم بيو:جار اثـر معنى دارى نسبت به شاهد ايجاد نكردند.

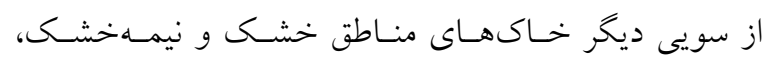

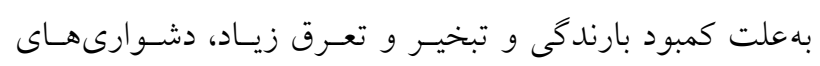
زيادى مانند تجمع نمكىهاى محلول يا شورى و ســيمى شـــن دارند و بهعلت كمبود و يا نبود يوشش كياهى كافى و باز گشـت مقدار كم بقاياى گياهى به خاك، ماده آلى كمسى دارنـد. تجزيـه

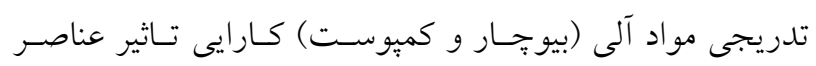
غذايى را افزايش مىدهد و باعث ماندگار شدن اثر اين تركيبات بر عملكرد كياهان و ويزگىىهاى خاك مىشود. استفاده از روش

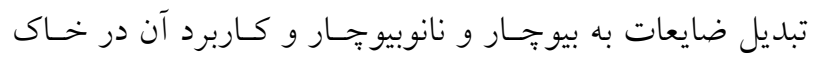

همجنين گروههاى عاملى بيوجار استفاده از بيو جار بهعنوان يك

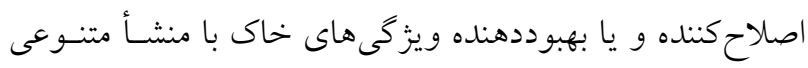
از ضايعات آلى كشاورزى و دامى و هم:جنسين روشهــاى تهيـهـ متفاوت مورد توجه قرار گرفته و در بزوهش هاى مختلفى اثر آن

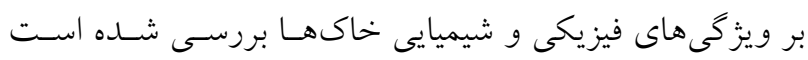

يزووهشخران آنـزيمهــاى خـاى را بـهـعنـوان شـاخص هـاى حاصلخيزى و كيفيت خاك بيشنهاد كردهاند. آنزيمهاى خـاى از طريق كاتاليز كـردن واكـنشهــاى بيولوزيـــ نقـش مـؤثرى در تجزيه بقاياى آلى، جرخه عناصـر غـذايى، تشـكيل مـاده آلى و ولى

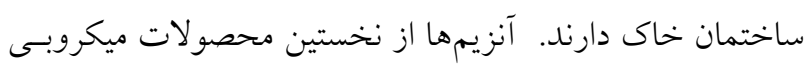

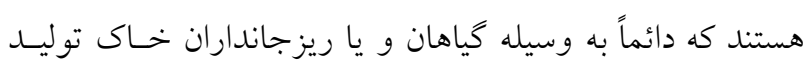
شده و مىتوانند در خاك بهصورت غيرفعال و يـاـــــ حتى تجزيـه شده تجمع يابند و به اين ترتيب در جرخحه عناصر در كشاورزى

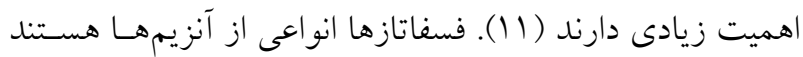

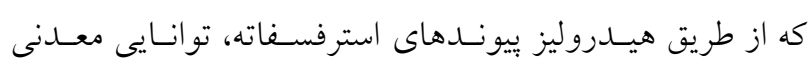
كردن فسـفر آلى خـاك را دارنـــ. در بـين اسـترهاى آلى اسـيد فسفريك در خاك، اسيد فيتانيك يا فيتين بيشترين سـهم را دارد.

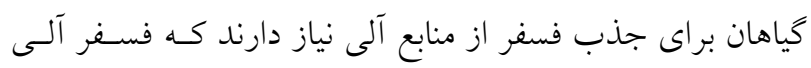
توسط فسفاتازها به ارتوفسفاتهاى اوليه تبديل شود. مهم تـرين انواع آن ها، فسفاتاز اسيدى و قليايى هستند كه به علت اهميـتـشان در معدنى شدن فسفر آلى خاك و تغذيه گياهـان، بـيش از ساير كروههاى فسفاتاز مـورد توجـهـ قــرار كرفتسهانـد. فسـفاتاز

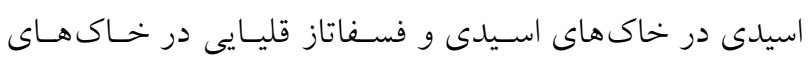

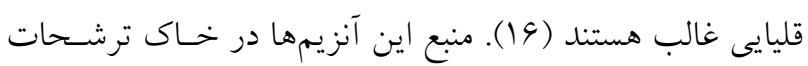
ريشهاى كياهان و ميكروب هاى خـاك اسـت. بنـابر اين فعاليـت

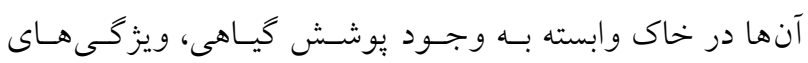
فيزيكى خاكها، مقدار و شدت فعاليت زيست توده ميكروبسى و

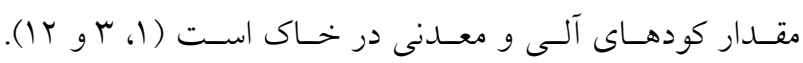
بيشتر كياهان تـوان توليــ فسـفاتاز قليـايى را ندارنــ، بنـابراين فسفاتاز قليايى بهطور عمـده توسـط ريزجانـداران خـاك توليـــ

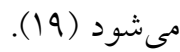


جدول ا. برخى ويثز گها و مكان نمونهبردارى خاكهاى مورد بررسى.

Table 1. Selected properties and sampling location of studied soils.

\begin{tabular}{|c|c|c|c|c|}
\hline & $\begin{array}{c}\text { آهكىى } \\
\text { Calcareous }\end{array}$ & شور سديمى شديد & شور سميدمى & اسيدى \\
\hline $\mathrm{pH}$ & 8.6 & 11.4 & 12.0 & 4.4 \\
\hline $\mathrm{EC}\left(\mathrm{dS} \mathrm{m} \mathrm{m}^{-1}\right)$ & 2.61 & 7.51 & 36.65 & 0.55 \\
\hline OC $(\%)$ & 0.67 & 0.54 & 0.21 & 4.37 \\
\hline $\operatorname{CCE}(\%)$ & 52.5 & 22.9 & 33.3 & 0.0 \\
\hline SAR & 7.7 & 285.2 & 20.1 & 3.1 \\
\hline $\operatorname{CEC}\left(\operatorname{cmol}(+) \mathrm{kg}^{-1}\right)$ & 11.0 & 7.3 & 22.7 & 68.9 \\
\hline بافت خاك & لوم شنى & لوم رسى سيلتى & لوم رسى & لوم رسى \\
\hline Soil texture & Sandy loam & Silty clay loam & Clay loam & Clay loam \\
\hline مكان نمونهبردارى & كبودر آهنگ & كبودر آهنش & كبودر آهنخ & لاهيجان \\
\hline Location & Kabodar-Ahang & Kabodar-Ahang & Kabodar-Ahang & Lahijan \\
\hline
\end{tabular}

EC: Electrical conductivity; OC: Organic carbon; CCE: Calcium carbonate equivalent; SAR: Sodium adsorption ratio; CEC: Cation exchange capacity.

سديمى بر فعاليت برخى آنزيمهاى مربـوط بـهـ جرخــه عناصـر كربن، فسفر و نيتروزن خاك انجام شده است.

\section{مواد و روشها - - ماد}

جهار نوع خاك رويين با ويزگگ هاى فيزيكى و شسيميايى متفـاوت

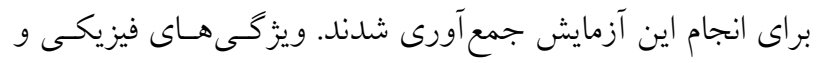

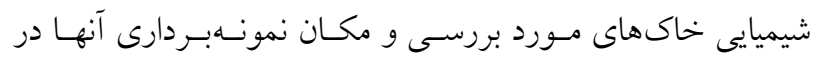

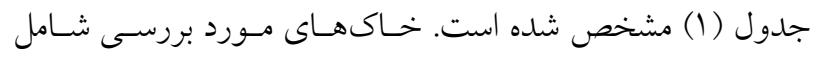

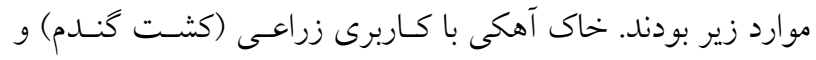

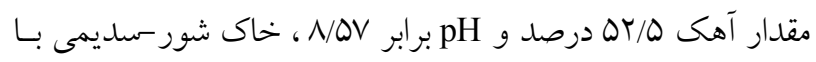

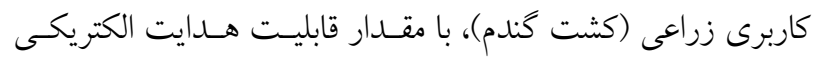

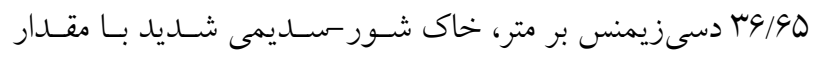

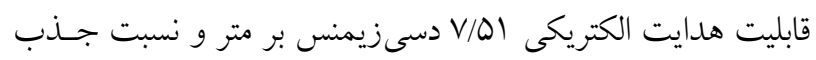

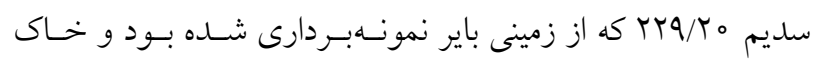

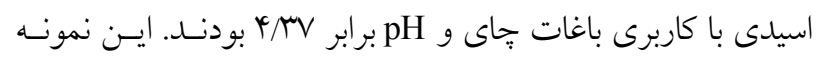

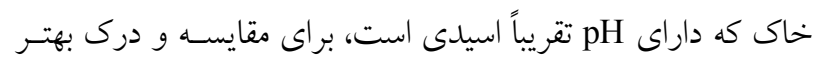

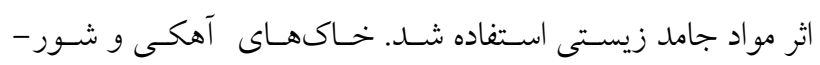

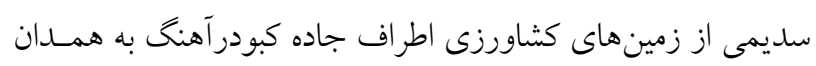
نمونهبردارى شد.
براى بهبود ويزگكىهاى خاى از جمله كارايى مصـرف آب و يـا

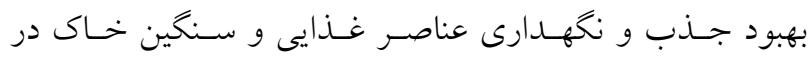

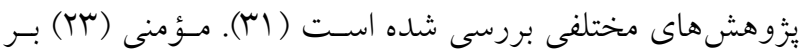

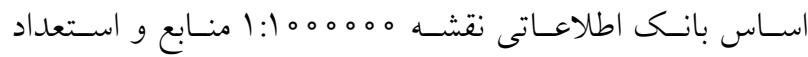
خاكهاى ايران، مساحت زمينهاى كشاورزى داراى محدوديت

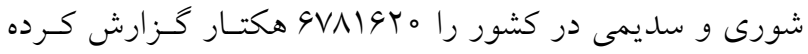

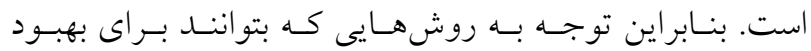

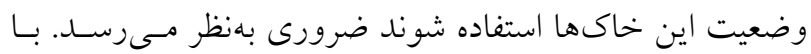

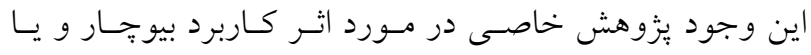

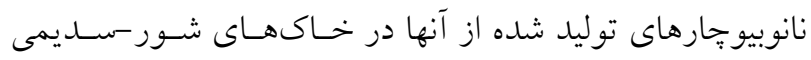

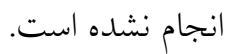

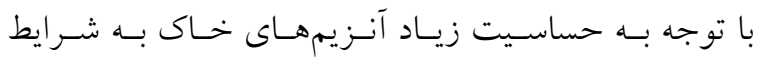

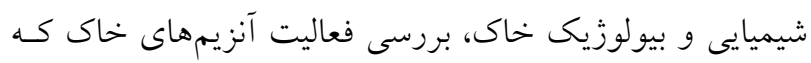
در جرخههـاى عناصـر فسـفر، نيتـروزن و كـربن مـؤثر هستـند

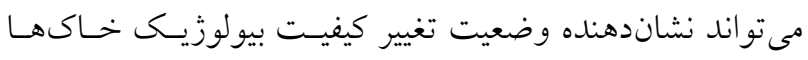

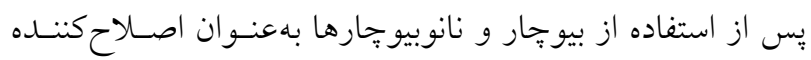

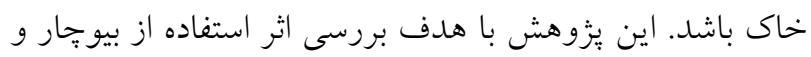

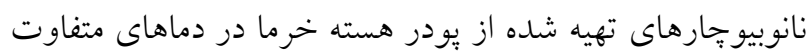

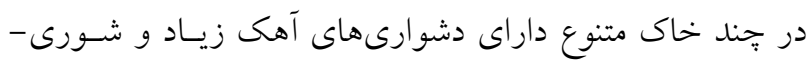


جدول Y. برخى ويزگگ هاى بيو جار، نانوبيو جار و نانوذره تهيه شده از يودر هسته خرما.

Table 2. Selected properties of date kernel's biochar, nano-biochar and nanoparticles.

\begin{tabular}{|c|c|c|c|c|c|c|}
\hline & DK & Bio 400 & Bio 800 & NBio 400 & Nbio 800 & NP \\
\hline $\mathrm{pH}$ & 7.58 & 7.69 & 8.10 & 7.86 & 8.24 & 7.62 \\
\hline $\mathrm{EC}\left(\mathrm{dS} \mathrm{m} \mathrm{m}^{-1}\right)$ & 3.51 & 4.48 & 5.77 & 4.26 & 6.67 & 3.59 \\
\hline OC (\%) & 3.57 & 4.30 & 4.57 & 5.76 & 6.28 & 5.17 \\
\hline
\end{tabular}

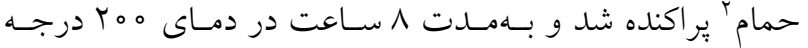
سلسيوس در اتوكلاو قرار داده شد. سبِ با سانتريفوز بهمـــ ها دقيقه جداسازى انجام گرفت. برخى ويزگگىهـاى تيمارهـاى مورد استفاده در جدول (r) آورده شده است. براى اجراى اين آزمـايش، خـاكهــا بـا ها درصـــ وزنسى از

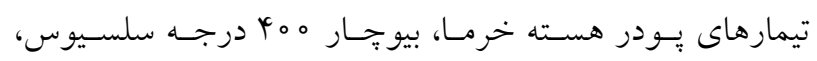

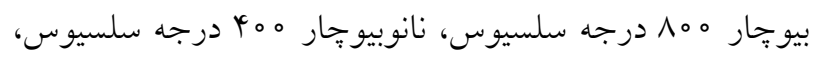
نانوبيوجــار مـ درجسه سلسـيوس و ا درصسد وزنسى نـانوذره مخلوط شده و به كلدانهاى ه ا كيلو گرمى منتقل شـدند. بـراى

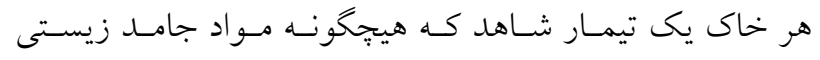
دريافت نكرده بود در نظر كرفته شد و بــراى انجـام آزمـايش بـ Borago officinalis ( تكرار تهيه شد. گياه گل كاوزبان ارويايى (L در كلدانهاى تيمار و شاهد كشت شده و يسس از م9 روز و

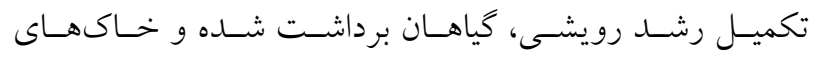
ريزوسفرى از خاى غيرريزوسفرى جدا شد. بـراى جـــاسـازى خاك ريزوسفرى از روش توريّالت (4) اسـتفاده شـد. يـس از خارج كردن ريشه كُهاه از گلدان، خاكهايى كه بدون تكان دادن

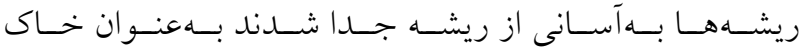
غيرريزوسفرى و خاكهايى كه به ريشه جسبيده بوده و يسس از

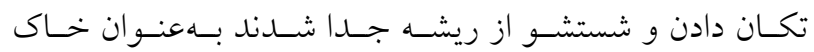
ريزوسفرى در نظر گرفته شد. براى بررسى و درك بهتر اثر تيمارهـا در فراينـدهاى خـاك،

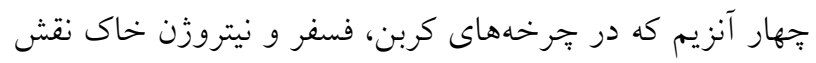

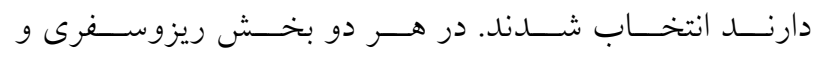

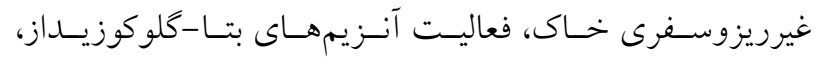

2. Bath usltrasound
هسته خرما از جمله ضايعات كشاورزى است كه حسدود Y I-4

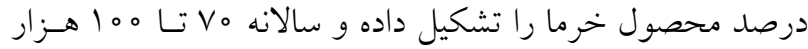
تن هسته خرما در كشور توليد مىشود. براى تهيه تيمارهـا ابتـدا هسته خرما آسياب شده و يـودر آن بـهـعــوان يكـى از تيمارهـا استفاده شد. درصد رطوبت يودر هسته خرما و جِّالى ظـاهرى

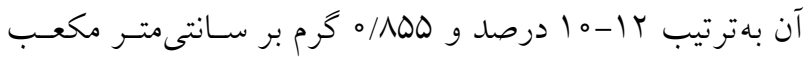
بود. يودر هسته خرما براى تهيه بيوجار استفاده شد. بـراى تهيـه.

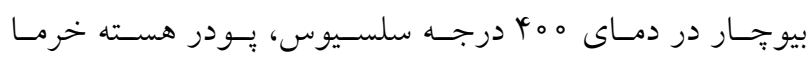

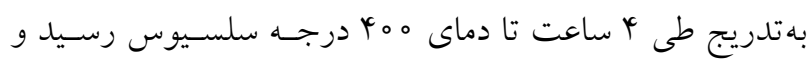
به مدت ها دقيقه در اين دما در شرايط بدون اكسيزن گرمادهى

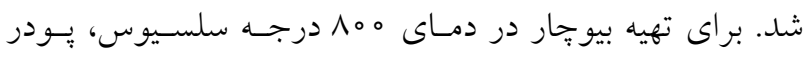
هسته خرما به تدريج در طى † أساعت در شرايط بــدون اكسـيزن به دماى 001 درجه سلسيوس رسيد و به مدت ه دقيقه در ايسن دما نخهدارى شد.. نسبت تبديل يـودر هسـته خرمـا بـه بيوجــار

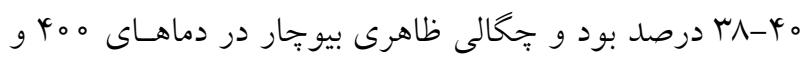

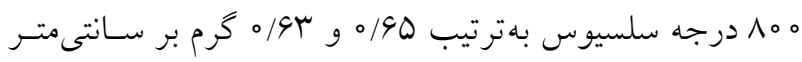
مكعب بهدست آمد. مقدارى از بيو جارهاى تهيه شده در هـر دو دما با روش آسياب كلولـهاى سـيارهاى' بـه نانوبيوجــار تبـديل شدند. مقدارى از هر بيوجار در كاسه دستخاه شيكر قرار گرفتـه و كلولههاى فلزى در سه اندازه به آن افزوده شده و بهمدت يكى ساعت شيك شد. سيس يودر حاصل با الكى انـدازه نـانو غربـال شد. همجنين در اين آزمايش با استفاده از روش هيدروترمال از يودر هسته خرما، نانوذره تهيه شـــ. در ايسن روش هـودر هسـته

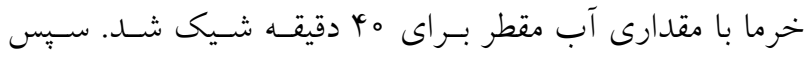

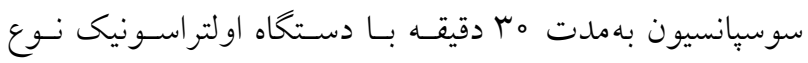

1. Planetary ball mill 


$$
\text { جدول r. تجزيه واريانس اثر نوع خاك، بيو جار و ريزوسفر بر آنزيمهاى اندازهيرى شده. }
$$

Table 3. Analysis of variance of the effect of soil type, biochars and rhizosphere on the measured enzymes.

\begin{tabular}{|c|c|c|c|c|c|c|c|}
\hline & \multicolumn{2}{|c|}{$\begin{array}{c}\text { فسفومونواستراز اسيدى } \\
\text { Acidic } \\
\text { Phosphomonoesterase }\end{array}$} & \multicolumn{2}{|c|}{ 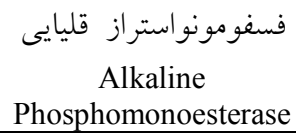 } & \multicolumn{2}{|r|}{$\begin{array}{c}\text { "يرو تئاز } \\
\text { Protease }\end{array}$} & \multirow{2}{*}{$\begin{array}{c}\text { بتا-گكلوكوزيداز } \\
\text { B-glucosidase } \\
\text { MS }\end{array}$} \\
\hline & $\mathrm{df}$ & MS & $\mathrm{df}$ & MS & $\mathrm{df}$ & MS & \\
\hline Soil & 3 & $10433^{* *}$ & 3 & $19672^{* *}$ & 3 & $12691^{* *}$ & $4788^{* *}$ \\
\hline Bio & 6 & $5340^{* *}$ & 6 & $5848^{* *}$ & 6 & $3498^{* *}$ & $1981^{* *}$ \\
\hline $\mathrm{Rh}$ & 1 & $9691^{* *}$ & 1 & $6960^{* *}$ & 1 & $7406^{* *}$ & $3427^{* *}$ \\
\hline Soil $\times$ Bio & 17 & $440^{* *}$ & 16 & $581^{* *}$ & 15 & $370^{* *}$ & $124^{* *}$ \\
\hline Soil $\times \mathrm{Rh}$ & 3 & $1331^{* *}$ & 3 & $294^{* *}$ & 3 & $813^{* *}$ & $13^{* *}$ \\
\hline $\mathrm{Rh} \times$ Bio & 6 & $97^{* *}$ & 6 & $47^{* *}$ & 6 & $58^{* *}$ & $13^{* *}$ \\
\hline Soil $\times$ Bio $\times$ Rh & 17 & $129^{* *}$ & 16 & $25^{* *}$ & 15 & $97^{* *}$ & $6^{* *}$ \\
\hline Res & 108 & 4 & 104 & 6 & 100 & 5 & 3 \\
\hline
\end{tabular}

Soil: نوع خاى، Bio: تيمارهاى استفاده شده، Rh: ريزوسفر-غير ريزوسفر، Res: باقيمانده، Df: درجه آزادى، MS: :DS: ميانخين مربعات.

Soil: Soil type; Bio: Applied treatments; Rh: Rhizosphere/Non-rhizosphere; Res: Residuals; Df: Degree of freedom; MS: Mean squares.

ريزوسفر و غيرريزوسفر با استفاده از روش دانكـن در سـطح درصد آمارى مقايسه شدند.

\section{نتايج و بحث}

جدول تجزيه واريانس آنزيمهاى اندازهيـرى شــه در جــدول

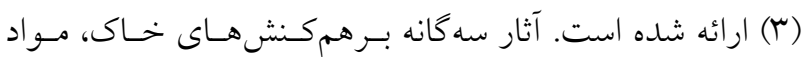
جامد زيستى و جايخاه ريزوسفرى بر همه آنزيمهاى اندازهكيرى شده در سطح احتمال ا درصد آمارى معنى دار شدند.

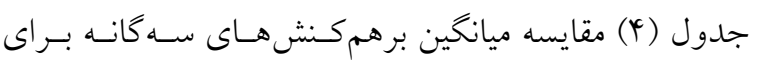
آنزيم فسفومونواستراز اسيدى را نشان مىدهد. بيشترين فعاليت آنزيم فسفومونواستراز اسيدى در خاك اسـيدى تيمـار شـاهد و كمترين مقادير در خـاك شـور ســــيمى شـديد تيمـار نـانوذره مشاهده شد. تفاوتهاى مشاهده شده بين خاكهاى مختلف در سطح ا درصد آمارى معنى دار بـود. بـيشتـرين فعاليـت آنـزيم فسفومنواستراز اسيدى در بخش ريزوسـفرى مشـاهده شــ كـه بهدليل اثر فعاليتهاى ريشه و ترشحات آن است. در بسيارى از خاكهاى مورد بررسى تفاوت معنىدارى بين بخش ريزوسفرى

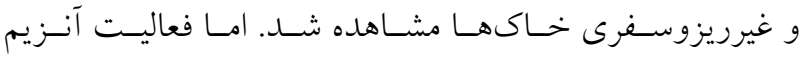
فسفومونواستراز اسيدى در بخشهاى ريزوسفر و غيرريزوسـفر خاك شور-سديمى شديد تفاوت معنى دارى نداشتند و افزايش
فسفومونواستراز اسيدى، فسفومونواسـتراز قليـايى و يروتئساز بـاــا

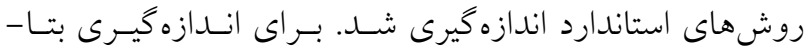
كلوكوزيداز يس از افزودن ساليسين بهاعنوان بستره، نمونـههـاى خاك بهمدت r ساعت در دماى V M درجه سلسيوس نكهـدارى شده و سبس مقدار ساليجين آزاد شده از بستره، در طـول مـوج OVA فسفومونواستراز اسيدى و فسفومونواستراز قليايى يّ از افزودن محلول بافر يارانيترو فنيل فسفات، نمونهها بهمدت يك سـاعت در دماى VV درجه سلسيوس نخهارى شده، يارانيترو فنـل آزاد شده در اثر فعاليت فسفومونو استرازهاى مختلف استخراج شده

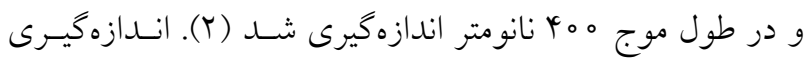
يروتئاز با استفاده از بستره كازئين انجام شد. نمونههاى خـاك و كازئين بهمدت r سـاعت در •ه درجسه سلسـيوس و pH برابـر

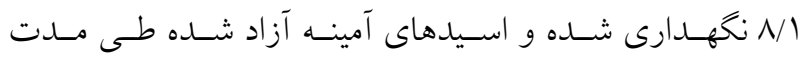
انكوباسيون استخراج شل. باقيمانده بستره بـهـوسـيله تـرى كلـرو

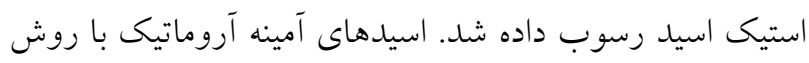
رنخسنجى اندازه گيرى شد (IV).

آزمايش انجام شده در قالب فاكتوريل بــا طـرح پِايسه كـاملاً تصادفى و با سه تكرار با استفاده از نرمافزار R تجزيه آمارى شد و ميانگين آثار اصلى و برهمكنش خاك و تيمارهـا در دو ناحيـه 
جدول أ. مقايسه ميانكين اثر كاربرد بيو:جار، نانوبيوجار و نانوذره تهيه شده از بودر هسته خرما در خاكهاى مختلف بر فعاليت آنزيم

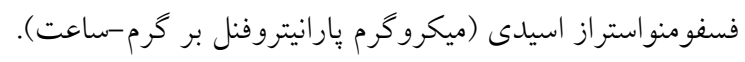

Table 4. Mean comparisons of the effect of application of date kernel's biochar, nano-biochar and nanoparticles in different soils on acidic phosphomonoesterase activity $\left(\mu \mathrm{g} \mathrm{pnp} \mathrm{g} \mathrm{g}^{-1} \mathrm{~h}^{-1}\right)$.

\begin{tabular}{|c|c|c|c|c|c|c|c|}
\hline NP & Nbio 800 & NBio 400 & Bio 800 & Bio 400 & DK & Blank & خاكها Soils \\
\hline \multicolumn{8}{|c|}{ ريزوسف Rhizosphere } \\
\hline $55.00 \mathrm{ghi}$ & $63.00^{\mathrm{f}}$ & $85.33^{\mathrm{d}}$ & $74.33^{\mathrm{e}}$ & $93.00^{c}$ & $121.00^{b}$ & $147.00^{\mathrm{a}}$ & \\
\hline $46.00^{j-n}$ & 32.00 tu & $47.67^{\mathrm{j}-\mathrm{m}}$ & $46.00^{j-n}$ & $50.33^{\mathrm{ijk}}$ & $63.67^{\mathrm{f}}$ & $74.67 \mathrm{e}$ & Calcareous \\
\hline $45.00^{\mathrm{j}-\mathrm{n}}$ & $41.67^{\mathrm{m}-\mathrm{q}}$ & $60.33 \mathrm{fg}$ & 55.33 ghi & $64.33^{f}$ & $72.33^{\mathrm{e}}$ & $88.33^{\mathrm{cd}}$ & شور سسديمى \\
\hline $35.00^{\text {rst }}$ & $36.00^{\mathrm{q}-\mathrm{t}}$ & $46.33^{j-n}$ & - & $38.33^{\mathrm{o}-\mathrm{s}}$ & $43.00^{1-p}$ & $50.00^{\mathrm{ijk}}$ & شور سمديمى شديد \\
\hline \multicolumn{8}{|c|}{ غيرريزوسفر Non-rhizosphere } \\
\hline $44.33^{\mathrm{k}-\mathrm{o}}$ & $40.33^{\mathrm{n}-\mathrm{r}}$ & $56.33 \mathrm{gh}$ & $44.67^{j-n}$ & $62.67^{\mathrm{f}}$ & $74.00^{\mathrm{e}}$ & $91.33^{\mathrm{c}}$ & اسيدى \\
\hline 29.33 uv & $40.00^{\mathrm{n}-\mathrm{r}}$ & $33.00 \mathrm{stu}$ & $35.67 \mathrm{q}-\mathrm{t}$ & $44.00^{\mathrm{k}-\mathrm{o}}$ & $55.67 \mathrm{ghi}$ & $64.33^{f}$ & Calcareous \\
\hline $32.00^{\text {tu }}$ & $36.00^{\mathrm{q}-\mathrm{t}}$ & $48.67 \mathrm{jkl}$ & $44.33^{\mathrm{k}-\mathrm{o}}$ & 51.00 hij & $60.33 \mathrm{fg}$ & $75.33^{\mathrm{e}}$ & شور سمديمى \\
\hline $20.67 \mathrm{w}$ & $25.00 \mathrm{vw}$ & $38.00^{p-t}$ & - & $27.67 \mathrm{uv}$ & $35.67 \mathrm{q}-\mathrm{t}$ & $47.00^{\mathrm{j}-\mathrm{m}}$ & شور سمديمى شديد \\
\hline
\end{tabular}

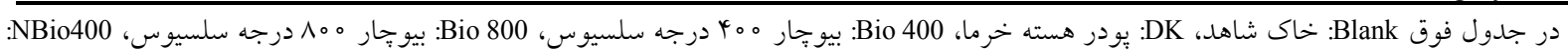

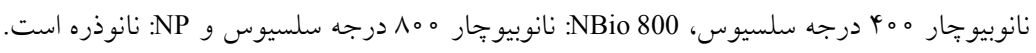

در كل جدول ميانگين هايى كه داراى حروف مشترى هستند بر اساس آزمون دانكن در سطح آمارى ا درصد اختلاف معنى دار ندارند.

Blank: Blank soil; DK: Date kernel; Bio 400: Biochar $400{ }^{\circ} \mathrm{C}$; Bio 800: Biochar $800{ }^{\circ} \mathrm{C}$; NBio 400: Nano-biochar $400{ }^{\circ} \mathrm{C}$; Nbio 800 : Nano-biochar $800^{\circ} \mathrm{C}$; NP: Nano-particle.

In table, numbers with similar letters are not significantly different (Duncan, $p<0.01$ ).

آنزيم فسفومونواستراز در خاى شور سسديمى شديد و بيشترين

فعاليت اين آنزيم در هر دو بخشهاى ريزوسفر و غيرريزوسـفر

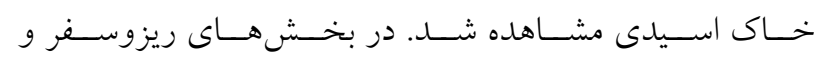

غيرريزوسفر جهـار خـاك مـورد بررسـى اسـتفاده از تيمارهـاى

بيو:جار باعث تفاوت معنىدارى اين آنزيم نسبت به تيمار شـاهد

شد. اما در خاك شور سـديمى شـديد، بخـش ريزوسـفر تيمـار

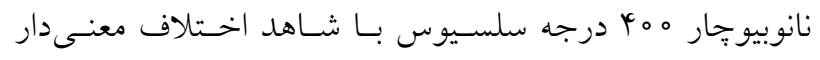

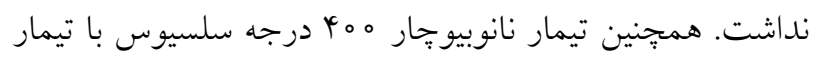

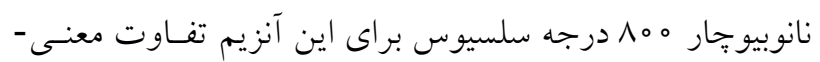

دارى بهوجود آورد (جدول fأهون).
معنى دارى در بخش ريزوسفر مشاهده نشد.

فعاليت آنزيم فسفومونواستراز اسيدى در تيمار شاهد (خاى

تنها) بيشتر بوده و بــا اعمـال تيمارهـاى بيو جــار و نانوبيوجـــار

فعاليت آنزيم كاهش جشم گيـرى يافـت. مقـادير ايسن آنـزيم بـا

كاربرد تيمارهاى بيو جار و نانوبيو جار در هر دو بخش ريزوسئمر

و غيرريزوسفر نسبت به تيمار شاهد كاهش يافت، اما در بخـش بـ نـ

ريزوسفر تمام خاكها فعاليت آنزيم بـيش از فعاليـت در بخـش

غيرريزوسفر بود. در بخشهاى ريزوسفر و غيرريزوسـفر خـاى

شور -سديمى فعاليت اين آنزيم نسبت به خاك آهكى بيشتر بود.

با اين حال در مقايسه بين تيمارهاى اعمال شده كمترين فعاليت 
جدول ه. مقايسه ميانكين اثر كاربرد بيو جار، نانوبيو جار و نانوذره تهيه شده از يودر هسته خرما در خاكهاى مختلف بر فعاليت آنزيم

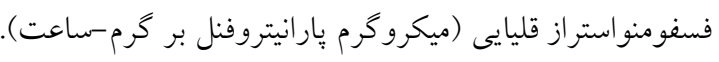

Table 5. Mean comparisons of the effect of application of date kernel's biochar, nano-biochar and nanoparticles in different soils on alkaline phosphomonoesterase activity $\left(\mu \mathrm{g} \mathrm{pnp} \mathrm{g} \mathrm{g}^{-1} \mathrm{~h}^{-1}\right)$.

\begin{tabular}{|c|c|c|c|c|c|c|c|}
\hline NP & Nbio 800 & NBio 400 & Bio 800 & Bio 400 & DK & Blank & خاكها Soils \\
\hline \multicolumn{8}{|c|}{ ريزوسفر Rhizosphere } \\
\hline \multirow[t]{2}{*}{$26.33^{w x}$} & \multirow[t]{2}{*}{$31.33^{\mathrm{vw}}$} & \multirow[t]{2}{*}{$43.33^{\text {rst }}$} & \multirow[t]{2}{*}{$28.00^{\mathrm{vwx}}$} & \multirow[t]{2}{*}{$33.33^{\mathrm{uv}}$} & \multirow[t]{2}{*}{$41.33^{\mathrm{st}}$} & \multirow[t]{2}{*}{$53.67^{\mathrm{n}-\mathrm{q}}$} & اسيدى \\
\hline & & & & & & & Acidic \\
\hline \multirow[t]{2}{*}{$47.00^{\mathrm{qrs}}$} & \multirow[t]{2}{*}{$47.33^{\mathrm{qrs}}$} & \multirow[t]{2}{*}{$59.67^{\operatorname{lmn}}$} & \multirow[t]{2}{*}{$52.00^{\text {opq }}$} & \multirow[t]{2}{*}{$66.67^{\mathrm{jk}}$} & \multirow[t]{2}{*}{$79.00^{\mathrm{fg}}$} & \multirow[t]{2}{*}{$86.00^{\mathrm{e}}$} & آهكى \\
\hline & & & & & & & Calcareous \\
\hline \multirow[t]{2}{*}{$43.33^{\text {rst }}$} & \multirow[t]{2}{*}{$52.33^{\mathrm{opq}}$} & \multirow[t]{2}{*}{$67.67^{\mathrm{ijk}}$} & \multirow[t]{2}{*}{84.00 ef } & \multirow[t]{2}{*}{$71.00^{\mathrm{hij}}$} & \multirow[t]{2}{*}{83.00 ef } & \multirow[t]{2}{*}{$96.67^{\mathrm{d}}$} & شور سـديمى \\
\hline & & & & & & & Saline-Sodic \\
\hline \multirow{3}{*}{$57.00 \mathrm{mno}$} & \multirow[t]{3}{*}{-} & \multirow{2}{*}{$84.33^{\text {ef }}$} & \multirow[t]{2}{*}{-} & \multirow{2}{*}{$93.67^{\mathrm{d}}$} & \multirow{3}{*}{$119.67^{b}$} & \multirow{3}{*}{$145.00^{\mathrm{a}}$} & شور سسديمى شديد \\
\hline & & & & & & & Saline-Highly Sodic \\
\hline & & Non & izosphere & غيرريز & & & \\
\hline \multirow[t]{2}{*}{$15.67^{\mathrm{y}}$} & \multirow[t]{2}{*}{$22.67^{x}$} & \multirow[t]{2}{*}{34.00 uv } & \multirow[t]{2}{*}{$14.00^{\mathrm{y}}$} & \multirow[t]{2}{*}{$23.67^{x}$} & \multirow[t]{2}{*}{34.67 uv } & \multirow[t]{2}{*}{$43.00^{\text {rst }}$} & 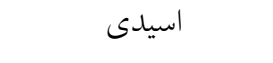 \\
\hline & & & & & & & Acidic \\
\hline $38.67^{\text {tu }}$ & 32.67 uv & $40.33 \mathrm{pqr}$ & $42.67^{\mathrm{rst}}$ & $55.33^{\text {nop }}$ & $63.00 \mathrm{klm}$ & 73.33 ghi & آهكى \\
\hline & & & & & & & Calcareous \\
\hline 34.00 uv & $41.67^{\text {st }}$ & $52.33^{\mathrm{opq}}$ & 73.33 ghi & $63.67 \mathrm{kl}$ & $73.67 \mathrm{ghi}$ & $79.33 \mathrm{fg}$ & شور سـديمى \\
\hline & & & & & & & Saline-Sodic \\
\hline $44.00^{\mathrm{rst}}$ & - & $61.67 \mathrm{klm}$ & - & $76.00 \mathrm{gh}$ & $94.00^{\mathrm{d}}$ & $109.00^{\mathrm{c}}$ & شور سسيمى شديد \\
\hline & & & & & & & Saline-Highly Sodic \\
\hline
\end{tabular}

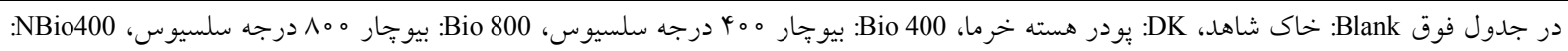

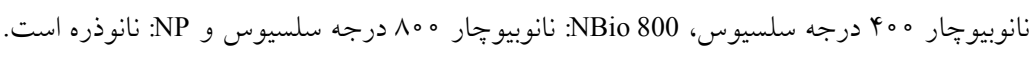

در كل جدول ميانگينهايى كه داراى حروف مشترك هستند بر اساس آزمون دانكن در سطح آمارى ا درصد اختلاف معنىدار ندارند.

Blank: Blank soil; DK: Date kernel; Bio 400: Biochar $400{ }^{\circ} \mathrm{C}$; Bio 800: Biochar $800{ }^{\circ} \mathrm{C}$; NBio 400: Nano-biochar $400{ }^{\circ} \mathrm{C}$; Nbio 800: Nano-biochar $800^{\circ} \mathrm{C}$; NP: Nano-particle.

In table, numbers with similar letters are not significantly different (Duncan, $p<0.01$ ).

خاكهاى اسيدى، آهكى و شور -سديمى شـديد باعـث شـد تـا تفاوت معنى دارى در فعاليت آنزيم فسفومنواستراز قليايى نسبت به تيمار شاهد مشاهده شود (جدول ه). بيشترين فعاليت آنزيم فسفومونواستراز قليايى در خاك شور -سديمى شديد و كمترين

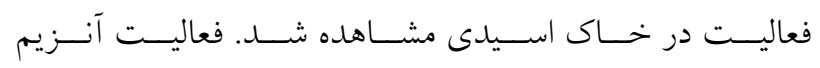
فسفومونواستراز قليايى در خاى اسيدى حدود يك سوم فعاليت

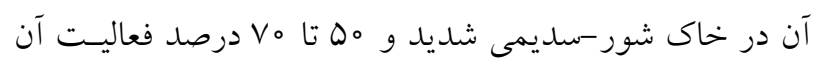
در خاكهاى آهكى و شور سـديمى بـود. بـا توجـهـ بـه ماهيـت

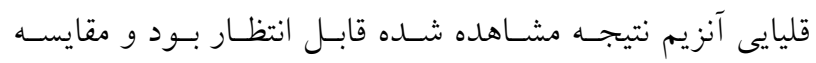

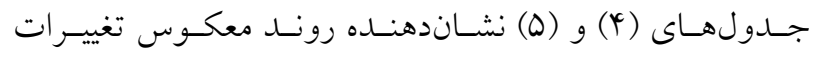

$$
\begin{aligned}
& \text { كاربرد بيو جار با دمـاى بيشـتر در فراينـــ توليـد باعـث شـــ تـا } \\
& \text { فعاليت آنزيم فسفومونواستراز اسيدى كاهش يابد. هر جنـــ كـه } \\
& \text { اين درصد كاهش در خاك اسيدى و بخش ريزوسفر بـيشتر و و }
\end{aligned}
$$

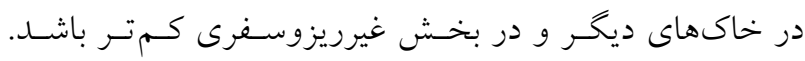

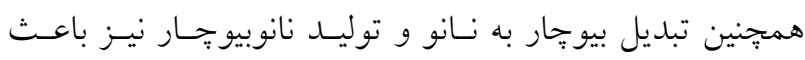

$$
\begin{aligned}
& \text { افزايش فعاليت اين آنزيم نشده و كمترين مقادير فعاليت آنـزيم } \\
& \text { در خاكهاى با كاربرد اين تيمارها ديده شد. }
\end{aligned}
$$

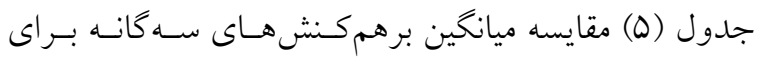

$$
\begin{aligned}
& \text { آنزيم فسفومونو استراز قليايى را نشان مىدهد. كاربرد تيمارهاى } \\
& \text { بيوجار و نانوبيوجهار در بخـشهــاى ريزوسـفر و غيرريزوسـفر }
\end{aligned}
$$


بررسى كرده و نشان دادنــ كـه در خـاك ريزوسـفرى فعاليـت

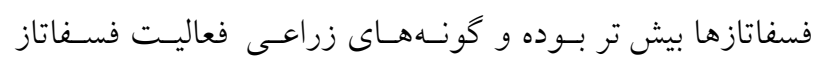

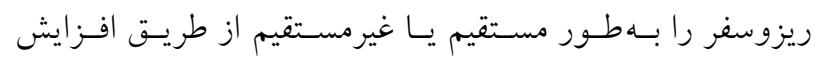
ترشحات ريشهاى و يا تحريك فعاليت ميكروبى افزايش دادهاند.

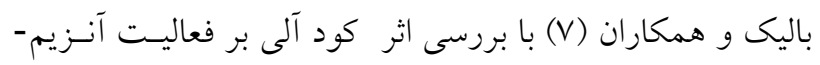

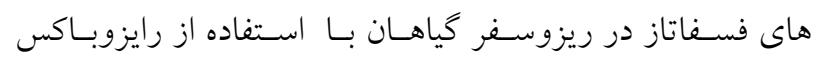

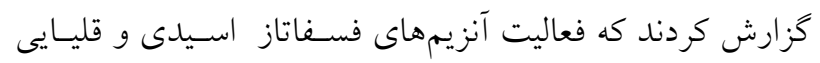
به طور معنى دارى نسبت به توده خاك افزايش يافت. جـن (10)

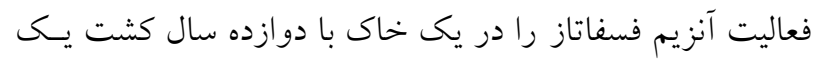
نوع درخت بومى جين، بررسى كـرد. نتسايج وى نشـان داد كـهـ

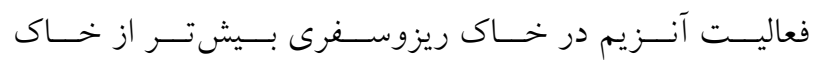

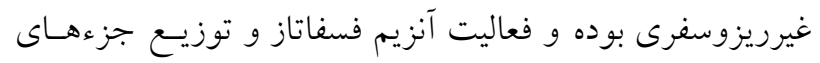

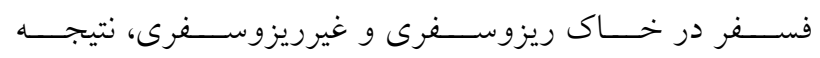

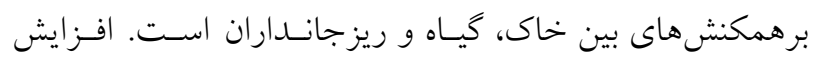

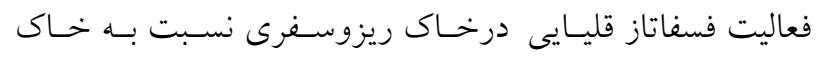
غيرريزوسفرى رامىتوان ناشى از فعاليت ميكروبسى و ريشـهاى

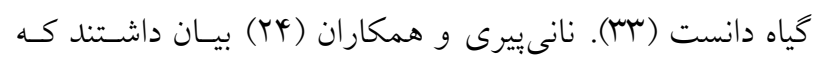

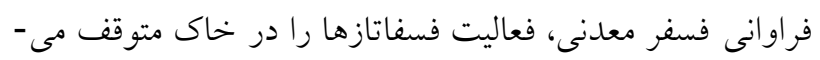

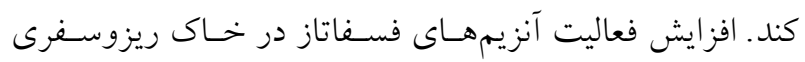

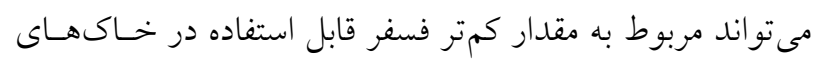

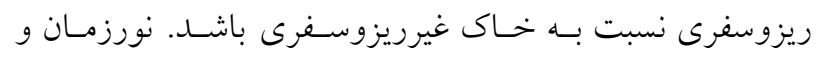

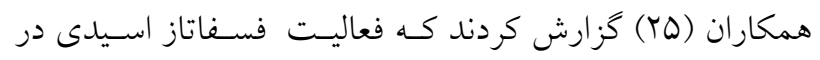

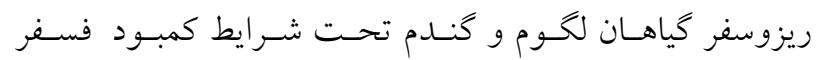

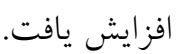
با توجه به ماهيت آنزيم فسفاتاز اسيدى، قليايى بودن خـاك

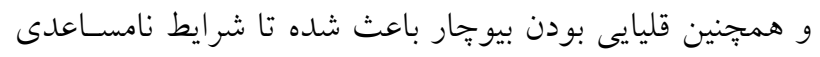

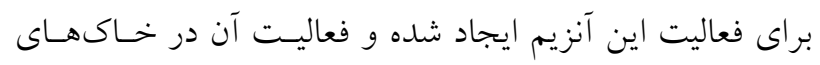

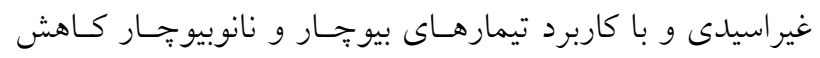

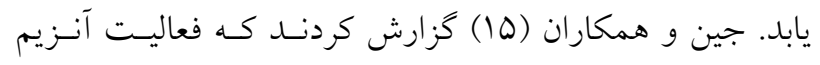

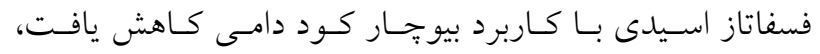
درحالى كه فعاليـت آنـزيم فسـفاتاز قليـايى افز ايش نشـان دادي

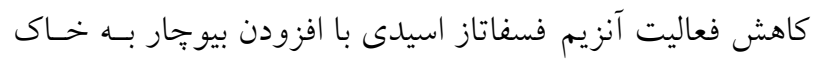

فعاليت دو آنزيم فسفومونواستراز اسيدى و قليايى در خاكهـاى

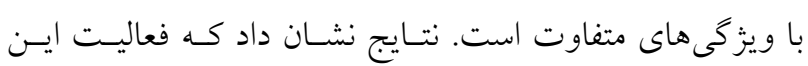

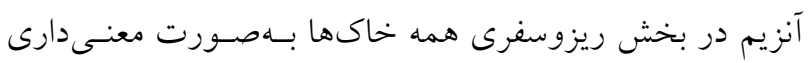

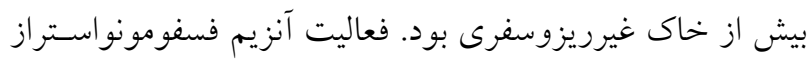

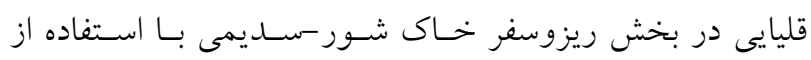

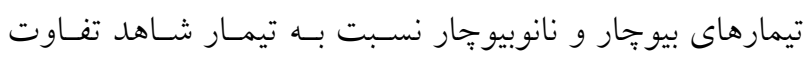

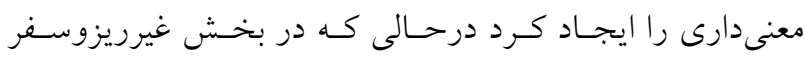

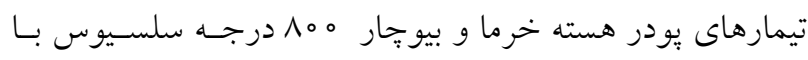

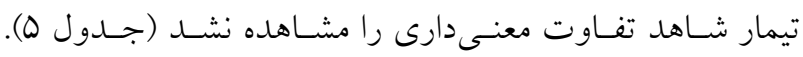
مقايسه كاربرد مواد جامد زيستى در خاكها نشان داد كه كاربرد

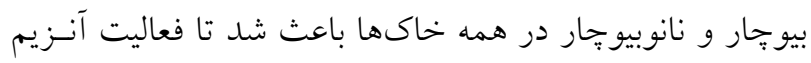
فسفومونواستراز قليايى كاهش يابد. اين كاهش در خاك اسسيدى

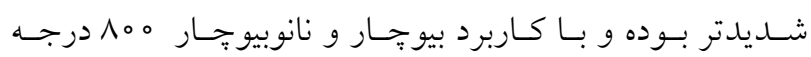

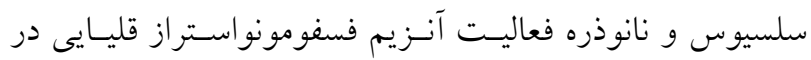
بخش ريزوسفر حدود مها درصد و در بخش غيرريزوسفرى تـا

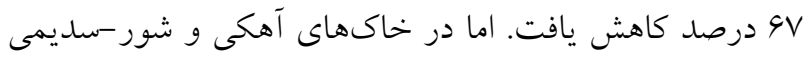

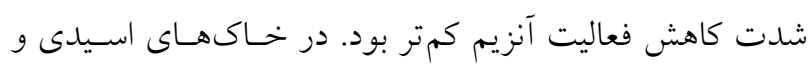

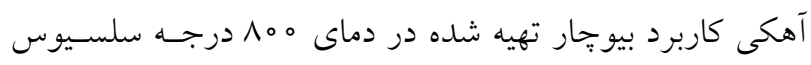
بهصورت معنىدارى باعث كاهش بيشتـرى در فعاليـت آنـزيم

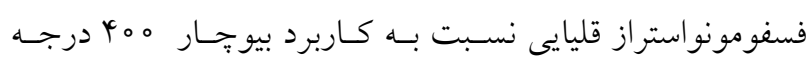

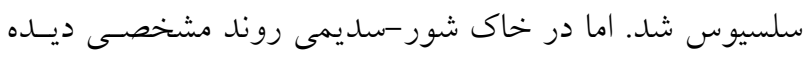
نشد. كاربرد نانوذره در همه خاكها باعث كاهش فعاليت آنـزيم

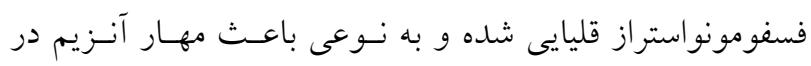

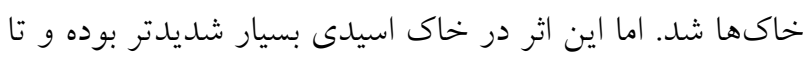

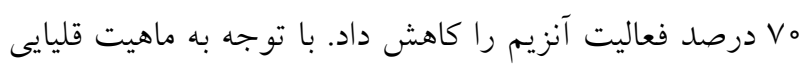

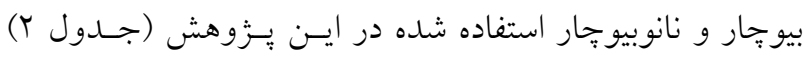

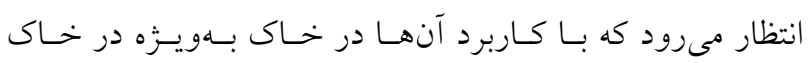

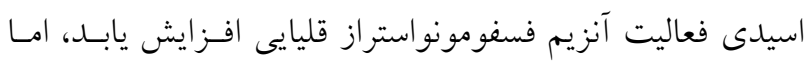

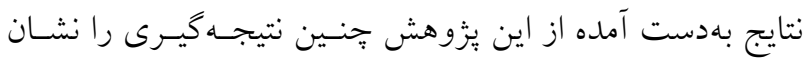
نمى دهل.

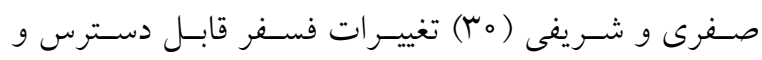
فعاليت فسفاتاز در ريزوسفر جند گياه زراعى و غيــ زراعسى را 
كه مواد اصلاحى دريافت نكــده بودنــــ از نظـــ فعاليـت آنـزيم

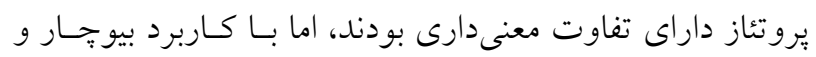

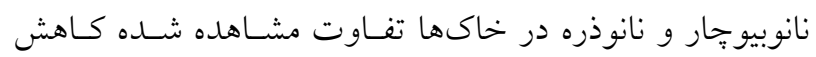

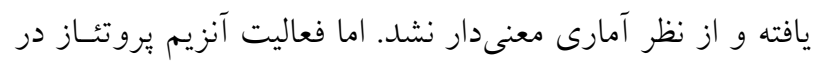

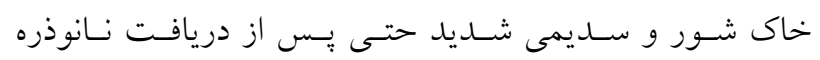

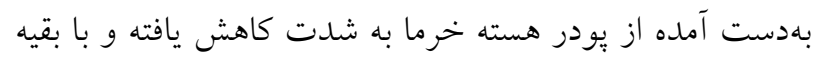

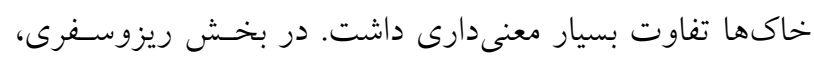

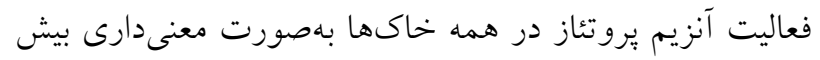

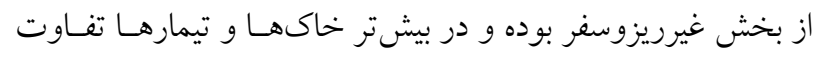

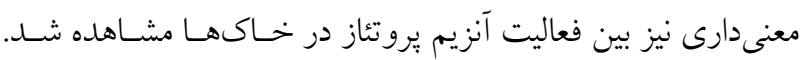

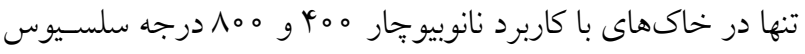

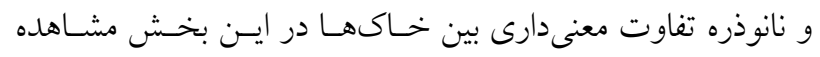

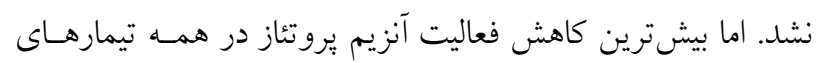

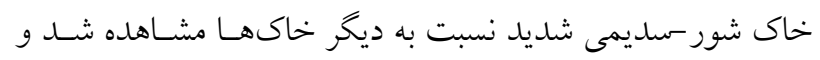

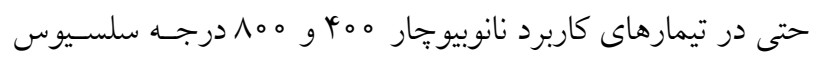
و نانوذره نيز تفاوت معنى دارى با بقيه خاكها داشت.

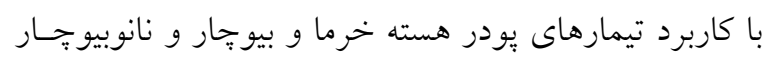

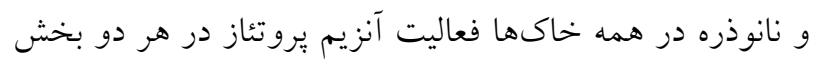

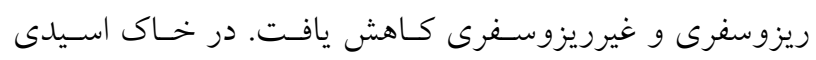

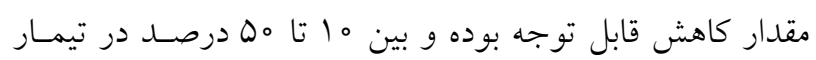

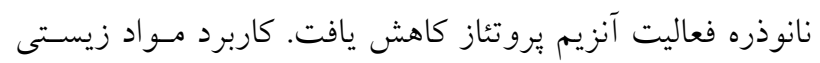

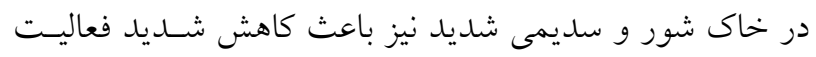

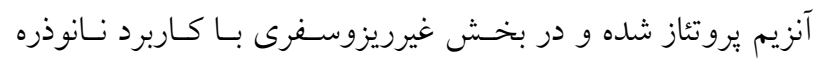

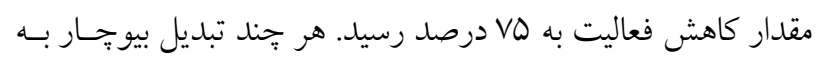

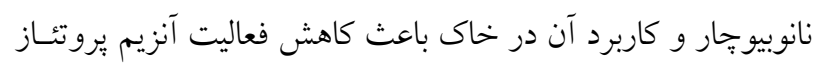

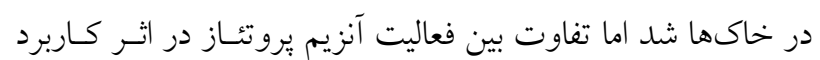

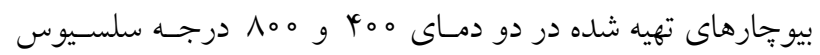

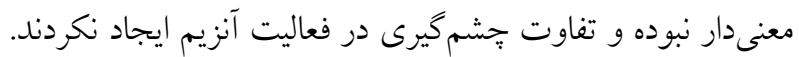

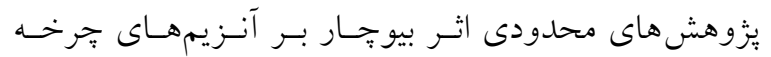

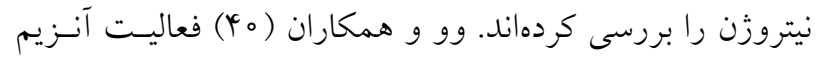

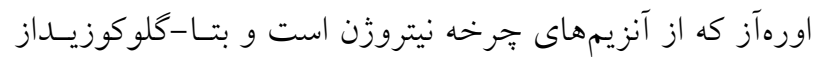

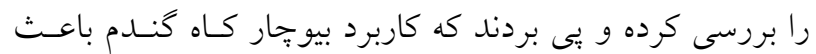

دور از انتظار نبود جرا كه خاك مورد بررسى آنها با pH قليايى

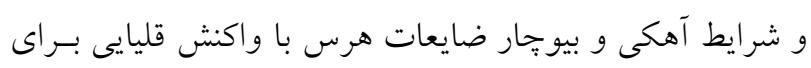

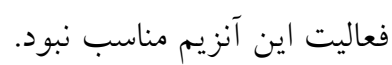

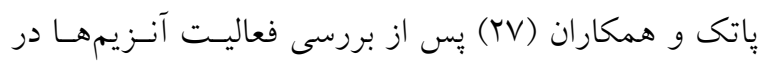

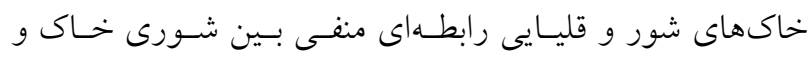

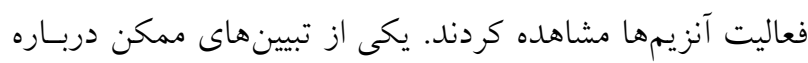

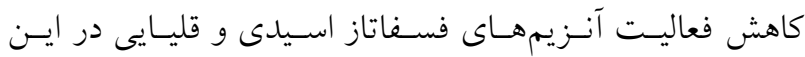

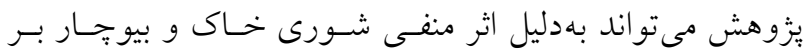

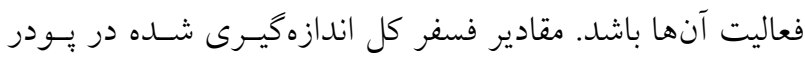

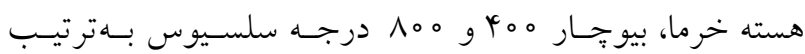

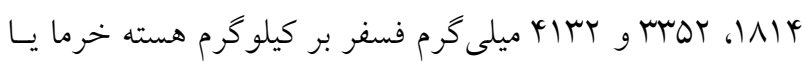
بيو جار بود. بنابراين با توجه به اينكه يودر هسته خرما و بيوجـار

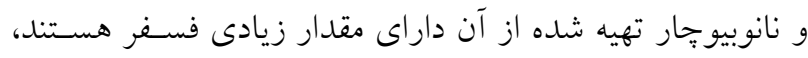
بر اساس يافتهاى نانىييرى و همكاران (YY)، كـاهش فعاليـت

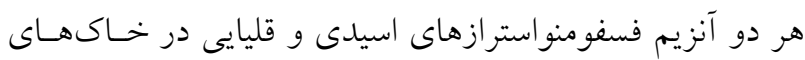

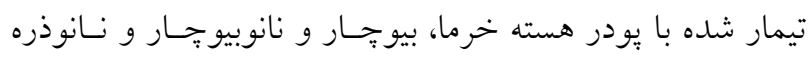

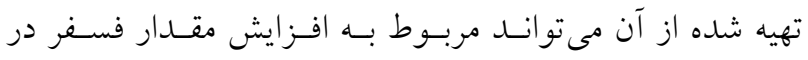

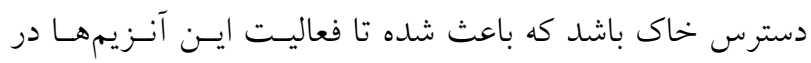

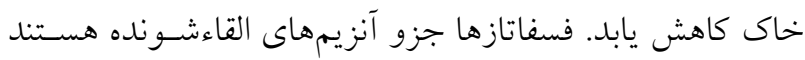

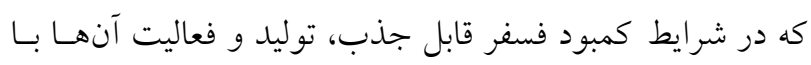

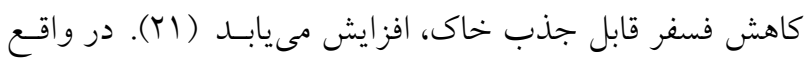

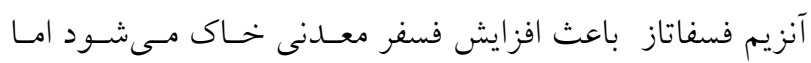

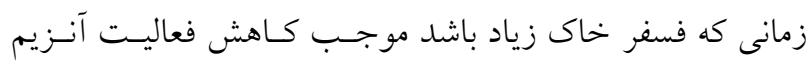

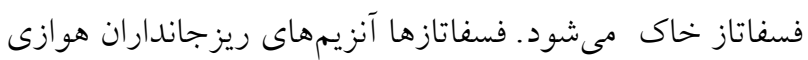

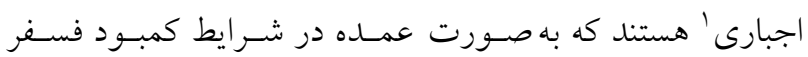
معلى قابل دسترس توليد مىشوند (YY).

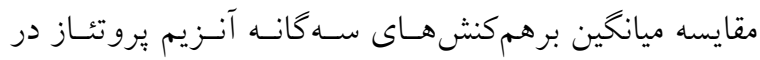
بخشهاى ريزوسفر و غير ريزوسفر خاكهاى مختلف در جدول

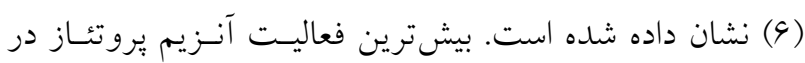

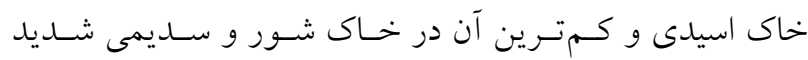
مشاهده شد. در بخش غيرريزوسفرى هر تهند خاكهاى شـاهد

1. Enzymes of obligate aerobes 
جدول و. مقايسه ميانكين اثر كاربرد بيو جار، نانوبيو جار و نانوذره تهيه شده از يودر هسته خرما در خاكهاى مختلف بر فعاليت آنزيم بروتئاز

$$
\text { (ميكرو گرم تيروزين بر كرم-ساعت). }
$$

Table 6. Mean comparisons of the effect of application of date kernel's biochar, nano-biochar and nanoparticles in different soils on Protease activity $\left(\mu \mathrm{g}\right.$ tyr g $\left.\mathrm{g}^{-1} \mathrm{~h}^{-1}\right)$.

\begin{tabular}{|c|c|c|c|c|c|c|c|}
\hline NP & Nbio 800 & NBio 400 & Bio 800 & Bio 400 & DK & Blank & خاكها Soils \\
\hline \multicolumn{8}{|c|}{ ريزوسفر Rhizosphere } \\
\hline $46.00^{\mathrm{k}-\mathrm{n}}$ & $51.00^{\mathrm{g}-\mathrm{k}}$ & $54.33^{\mathrm{f}-\mathrm{i}}$ & $61.67^{\mathrm{de}}$ & $64.33^{d}$ & $77.33^{b}$ & $86.00^{a}$ & اسيدى \\
\hline $49.33^{\mathrm{i}-\mathrm{m}}$ & $52.00^{\mathrm{g}-\mathrm{j}}$ & $65.00^{\mathrm{d}}$ & $52.67^{\mathrm{f}-\mathrm{j}}$ & $57.67^{e-j}$ & $62.00^{\mathrm{de}}$ & $79.33^{b}$ & آهكى \\
\hline $44.67^{\mathrm{lmn}}$ & $49.33^{\mathrm{i}-\mathrm{m}}$ & $53.67^{f-i}$ & $44.00^{\text {no }}$ & $49.67^{\mathrm{kl}}$ & $58.00^{\mathrm{ef}}$ & $64.00^{\mathrm{d}}$ & شور سميمىى \\
\hline $19.67^{\mathrm{s}}$ & - & - & - & $33.67^{q}$ & $39.00^{\text {op }}$ & $43.67^{\mathrm{mno}}$ & شور سسديمى شديد \\
\hline \multicolumn{8}{|c|}{ غيرريزوسفر Non-rhizosphere } \\
\hline $35.67 \mathrm{pq}$ & $41.33^{n-1}$ & $46.33^{\mathrm{k}-\mathrm{n}}$ & $52.00^{g-j}$ & $54.00^{f-i}$ & $62.67^{\mathrm{de}}$ & $71.33^{c}$ & اسيدى \\
\hline $39.00^{\text {op }}$ & $45.33^{\mathrm{mn}}$ & $56.00^{\mathrm{f}-\mathrm{m}}$ & $47.67^{\mathrm{j}-\mathrm{m}}$ & $49.33^{\mathrm{i}-\mathrm{m}}$ & $55.33 \mathrm{fgh}$ & $66.00^{\mathrm{d}}$ & آهكى \\
\hline $32.00^{\mathrm{q}}$ & $41.00^{\text {no }}$ & $46.00^{n}$ & $33.67^{q}$ & $42.00^{\text {no }}$ & $51.00^{\mathrm{g}-\mathrm{k}}$ & $55.00^{\mathrm{f}-\mathrm{i}}$ & شور سمديمى \\
\hline $9.33^{\mathrm{t}}$ & - & - & - & $24.33^{r}$ & $30.67^{q}$ & $32.00^{q}$ & شور سـديمى شديل \\
\hline
\end{tabular}

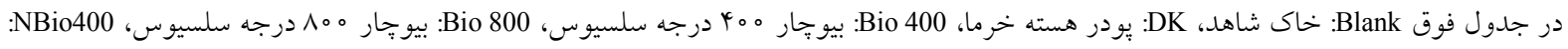

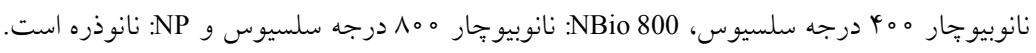

در كل جدول ميانكينهايى كه داراى حروف مشترك هستند بر اساس آزمون دانكن در سطح آمارى ا درصد اختلاف معنىدار ندارند.

Blank: Blank soil; DK: Date kernel; Bio 400: Biochar $400{ }^{\circ} \mathrm{C}$; Bio 800: Biochar $800{ }^{\circ} \mathrm{C}$; NBio 400: Nano-biochar $400{ }^{\circ} \mathrm{C}$; Nbio 800 : Nano-biochar $800^{\circ} \mathrm{C}$; NP: Nano-particle.

In table, numbers with similar letters are not significantly different (Duncan, $p<0.01$ ).

آنزيمها به كاربرد بيو جار و ورود منابع اضـافى كـربن و عناصـر

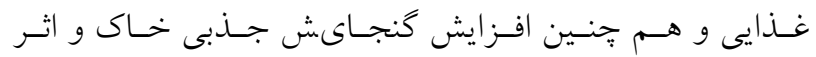
غيرمستقيم آن در نخهدارى آب نسبت داده شد. ايشان بيى بردنــ كه اثر منفى بيو جار بر فعاليت آنزيمى به كنجاىش زياد جـذب سطحى بيو:جار براى سوبستراى آنزيم بستخى دارد (Y)). وانـ و همكاران (مب) در يك خاك با رزيم رطوبتى آكوئيك مشاهده كردند كه افزودن بيو:حار ذرت باعث افزايش فعاليت آنزيمهـاى

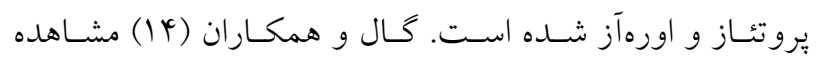
كردند كه اسـتفاده از دمـاى زيـادتر بيروليـز اغلـب بيوزجارهـاى

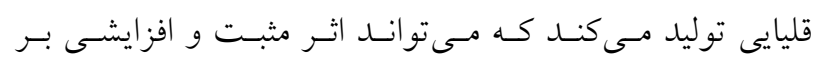

$$
\begin{aligned}
& \text { افزايش فعاليت اورهآز و كاهش فعاليت آنـزيم بتــا-كلو كوزيــداز } \\
& \text { شد. اولسكزو ك و همكاران (Y) نيز اثر آفت كث ها را بر گيـاه، } \\
& \text { ميكروبـها و فعاليت آنزيمى در حضور مقادير هب و ه广 تـن در } \\
& \text { هكتار بيوجيار دماى •ه } 9 \text { درجه سلسيوس بررسى كردنـد. نتـايج } \\
& \text { به دست آملهه حاكى از تحريك فعاليت آنزيمى توسط بيوتجار و } \\
& \text { كاهش اثر آفت كش بر فعاليت آنزيمسى و كـروههــاى خاصسى از } \\
& \text { ميكروبـها بود. در اين يزّوهش فعاليت آنزيمهاى دهيـدروزناز، }
\end{aligned}
$$

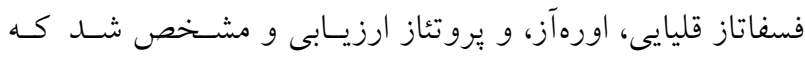

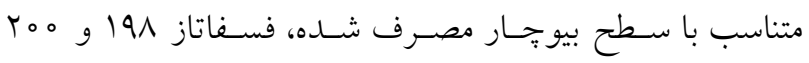

$$
\begin{aligned}
& \text { درصد و تيروتئاز VY و V درصد افزايش يافت. افـزايش فعاليـت }
\end{aligned}
$$


جدول V. مقايسه ميانحين اثر كاربرد بيو:حار، نانوبيو:حار و نانوذره تهيه شده از يودر هسته خرما در خاكهاى مختلف بر فعاليت آنزيم بتا-

$$
\text { كلوكوزيداز (ميكرو گرم ساليجين بر كرم-ساعت). }
$$

Table 7. Mean comparisons of the effect of application of date kernel's biochar, nano-biochar and nanoparticles in different soils on $\beta$-glucosidase activity $\left(\mu \mathrm{g}\right.$ saligen $\left.\mathrm{g}^{-1} \mathrm{~h}^{-1}\right)$.

\begin{tabular}{|c|c|c|c|c|c|c|c|}
\hline NP & Nbio 800 & NBio 400 & Bio 800 & Bio 400 & DK & Blank & ناكها Soils \\
\hline \multicolumn{8}{|c|}{ ريزوسفر Rhizosphere } \\
\hline \multirow[t]{2}{*}{$55.00^{\mathrm{hij}}$} & \multirow[t]{2}{*}{$65.00^{f}$} & \multirow[t]{2}{*}{$87.00^{\mathrm{d}}$} & \multirow[t]{2}{*}{$81.00^{\text {de }}$} & \multirow[t]{2}{*}{$92.67^{c}$} & \multirow[t]{2}{*}{$107.00^{\mathrm{b}}$} & \multirow[t]{2}{*}{$131.00^{\mathrm{a}}$} & اسيدى \\
\hline & & & & & & & Acidic \\
\hline \multirow[t]{2}{*}{$44.33^{1-0}$} & \multirow[t]{2}{*}{$54.33^{\mathrm{hij}}$} & \multirow[t]{2}{*}{$42.33^{\mathrm{mno}}$} & \multirow[t]{2}{*}{$60.33^{\mathrm{fgh}}$} & \multirow[t]{2}{*}{$52.33^{\mathrm{ijk}}$} & \multirow[t]{2}{*}{$63.67 \mathrm{fg}$} & \multirow[t]{2}{*}{$77.00^{\mathrm{e}}$} & آهكى \\
\hline & & & & & & & Calcareous \\
\hline \multirow[t]{2}{*}{$49.33^{\mathrm{j}-\mathrm{m}}$} & \multirow[t]{2}{*}{$45.33^{\operatorname{lmn}}$} & \multirow[t]{2}{*}{$56.33^{\text {hij }}$} & \multirow[t]{2}{*}{54.67 hij } & \multirow[t]{2}{*}{$63.67 \mathrm{fg}$} & \multirow{2}{*}{$76.00^{\mathrm{e}}$} & \multirow{2}{*}{$82.00^{\text {de }}$} & شور سسديمى \\
\hline & & & & & & & Saline-Sodic \\
\hline \multirow{3}{*}{$23.67^{\mathrm{s}}$} & \multirow{3}{*}{ - } & \multirow{2}{*}{-} & \multirow{2}{*}{ - } & \multirow{2}{*}{$28.67^{\mathrm{rs}}$} & \multirow{3}{*}{$25.00^{\mathrm{s}}$} & \multirow{3}{*}{$34.67 \mathrm{pqr}$} & شور سمديمى شديد \\
\hline & & & & & & & Saline-Highly Sodic \\
\hline & & Non & فر osphere & 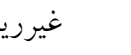 & & & \\
\hline \multirow[t]{2}{*}{$43.33^{\mathrm{mno}}$} & \multirow[t]{2}{*}{$46.00^{\mathrm{k}-\mathrm{n}}$} & \multirow[t]{2}{*}{$57.67 \mathrm{ghi}$} & \multirow[t]{2}{*}{53.67 hij } & \multirow[t]{2}{*}{$64.00^{\mathrm{fg}}$} & \multirow[t]{2}{*}{$81.67^{\mathrm{de}}$} & \multirow[t]{2}{*}{$93.33^{c}$} & اسيدى \\
\hline & & & & & & & Acidic \\
\hline 37.67 opq & $43.33^{\mathrm{m}-\mathrm{o}}$ & $54.00^{\mathrm{hij}}$ & $40.67^{\text {nop }}$ & $47.00^{\mathrm{k}-\mathrm{n}}$ & $51.00^{\mathrm{i}-1}$ & $64.67^{\mathrm{f}}$ & آهكى \\
\hline & & & & & & & Calcareous \\
\hline 37.67 opq & $34.67 \mathrm{pqr}$ & $41.33^{\text {no }}$ & $44.33^{1-\mathrm{o}}$ & $46.33^{\mathrm{k}-\mathrm{n}}$ & 55.00 hij & $66.00^{f}$ & شور سسديمى \\
\hline & & & & & & & Saline-Sodic \\
\hline $12.00^{\mathrm{t}}$ & - & - & - & $24.67^{\mathrm{s}}$ & $28.67^{\mathrm{rs}}$ & $32.33^{\mathrm{qr}}$ & شورسديمى شديد \\
\hline & & & & & & & Saline-Highly Sodic \\
\hline
\end{tabular}

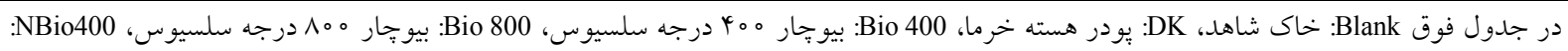

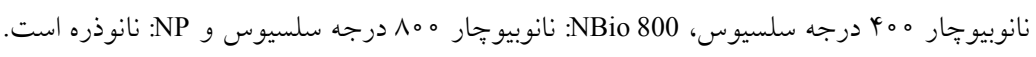

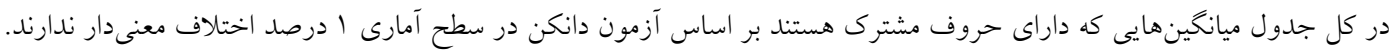

Blank: Blank soil; DK: Date kernel; Bio 400: Biochar $400{ }^{\circ} \mathrm{C}$; Bio 800: Biochar $800{ }^{\circ} \mathrm{C}$; NBio 400: Nano-biochar $400{ }^{\circ} \mathrm{C}$; Nbio 800: Nano-biochar $800{ }^{\circ} \mathrm{C}$; NP: Nano-particle.

In table, numbers with similar letters are not significantly different (Duncan, $p<0.01$ ).

ريزجانداران در محدوده آن و موادى كه از ريشهها ترشح مسى شود بهصورت معنسىدارى فعاليـت آنـزيم بتـا-كلوكوزيــاز در بخش ريزوسفرى بيشتر از بخـش غيرريزوسـفرى بـود. تنهـا در

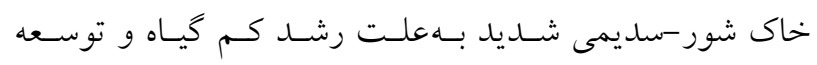
ضعيف ريشه ها تفاوت معنسى دارى بـين دو بخـش ريزوسـفر و غيرريزوسفرى ديده نشد (جدول V).

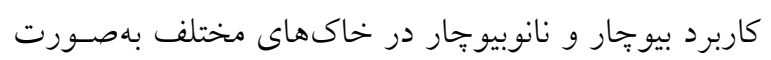

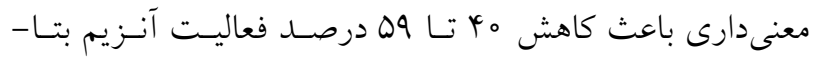

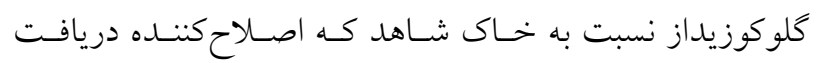

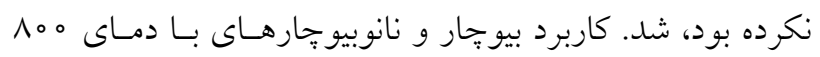

$$
\begin{aligned}
& \text { آنزيمهاى جرخه نيتروزن داشته باشـد. امـا در يـرزوهش حاضـر }
\end{aligned}
$$

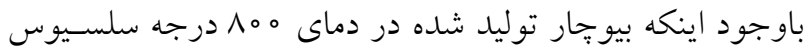

$$
\begin{aligned}
& \text { قليايىتر بود اما كاربرد آن در خاك باعث كاهش فعاليـت آنـزيم } \\
& \text { يروتئاز شد. }
\end{aligned}
$$

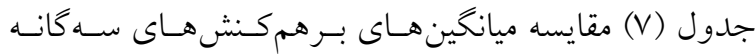

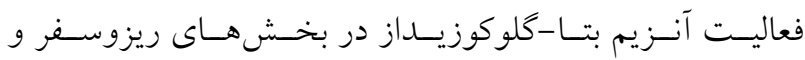

$$
\begin{aligned}
& \text { غيرريزوسفرى خاكهاى مختلـف در اتــر تيمارهـاى بيوجـار و }
\end{aligned}
$$

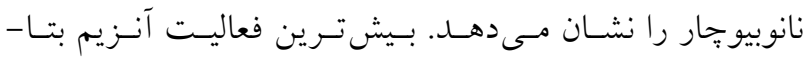

$$
\begin{aligned}
& \text { كلوكوزيداز در خاك اسيدى و كـمتـرين فعاليـت آن در خـاى } \\
& \text { شور و سديمى شديد مشــاهده شـــ. بــدليـل فعاليـت ريشـهـ و }
\end{aligned}
$$




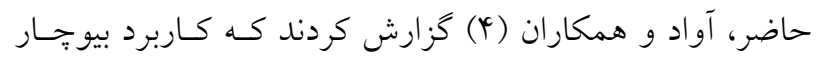

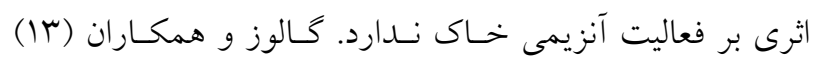

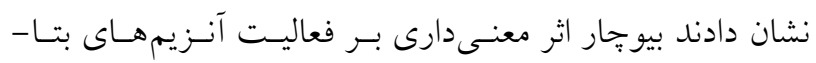

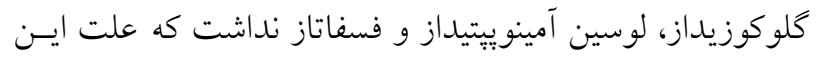

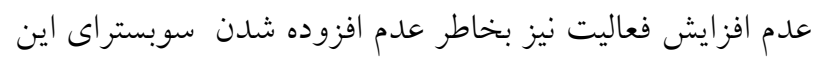

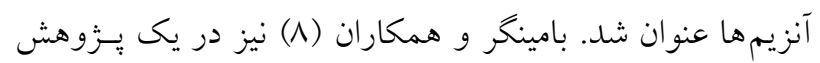

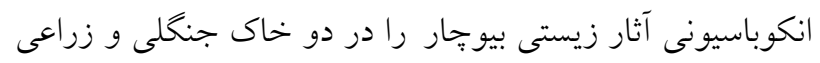

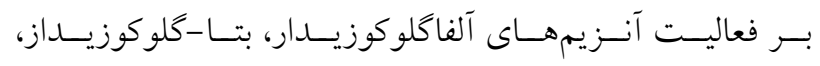

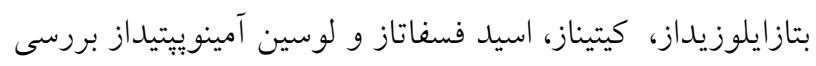

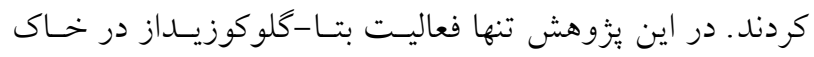

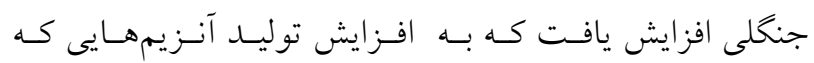
سوبستراى آنها موجود است، نسبت داده شد.

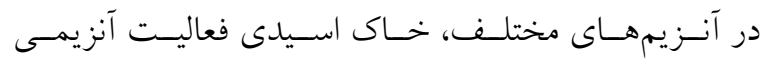

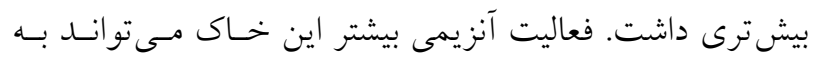

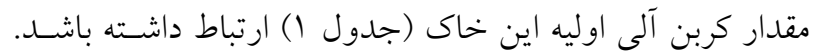

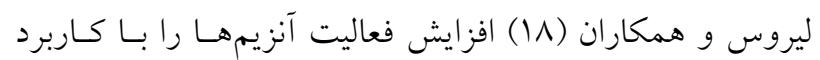
مواد آلى كزارش كردند. درصورتى كه خاكهــاى ديخـــ مقــدار

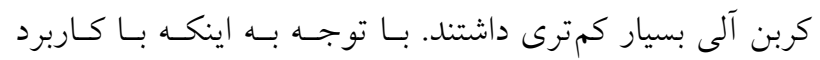

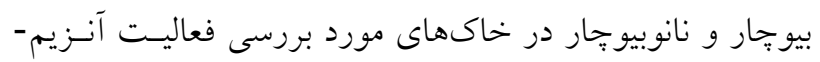

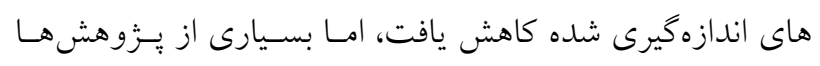

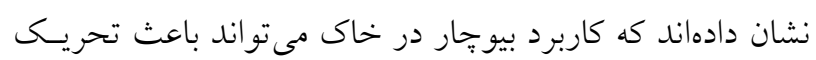

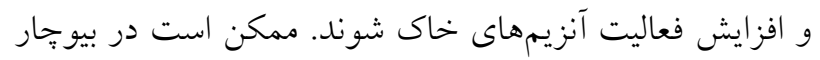

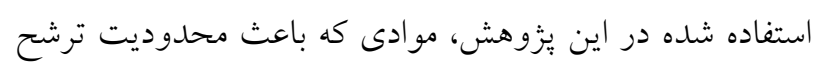

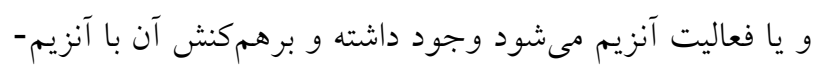

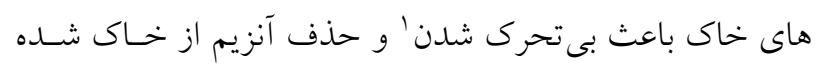

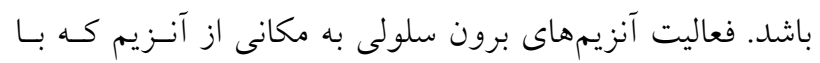
سطح ذرات بيو:جار برهم كنش مىدهد، بستخى دارد. اخر جايخاه

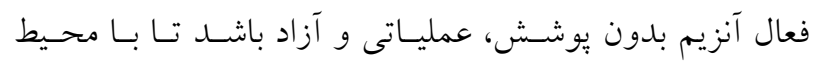

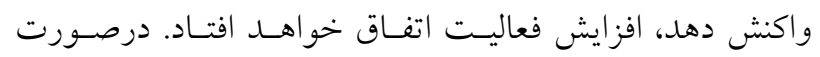
مسدود شدن جايگاه فعال، فعاليـت كـاهش خواهـــ يافـت (9).

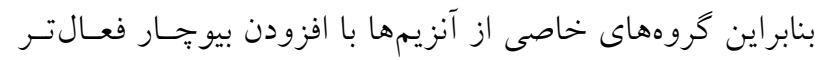

درجه سلسـيوس باعـث كـاهش بيشـترى نسـبت بـه بيوجـار و

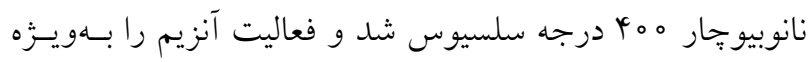
در بخش ريزوسفرى بهصورت معنسى دارى كـاهش داد. كـاربرد

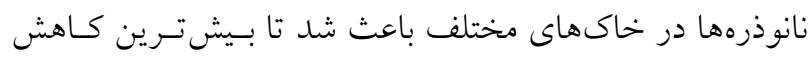

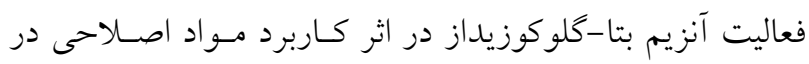
خاكها مشاهده شـود و ايـن شـدت كـاهش در خـاك اسـيدى شدت بيش ترى داشته و تـا هو درصـــ باعـث كـاهش فعاليـت

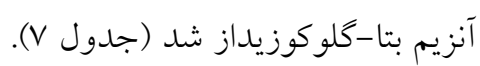

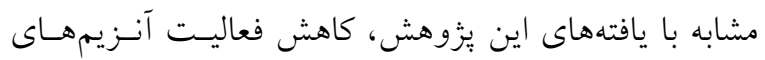

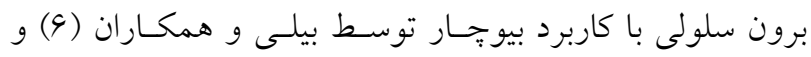

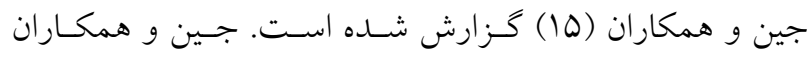

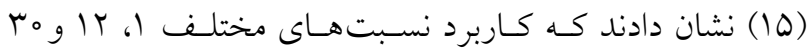

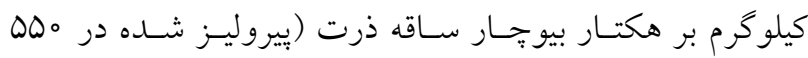

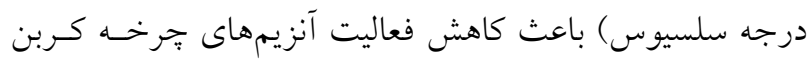

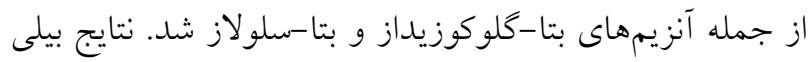
و همكاران (9) نيز نشان داد كه فعاليت آنـزيم بتـا-كلوكوزيسـاز

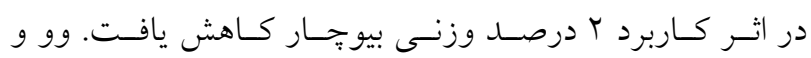

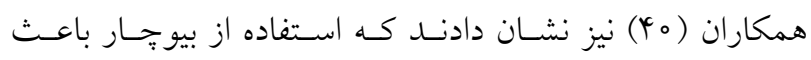

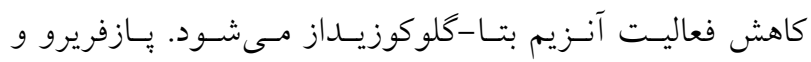

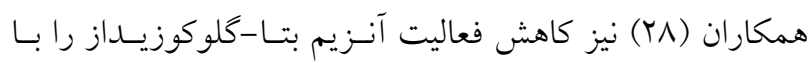

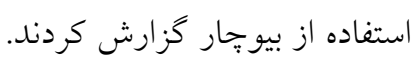

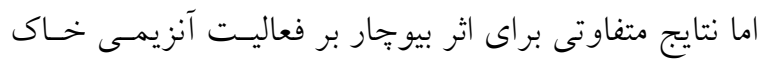
كزارش شده است. بيلى و همكاران (9) نشـان دادنـــ كـــ آثـار

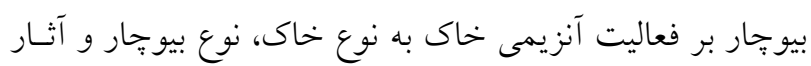

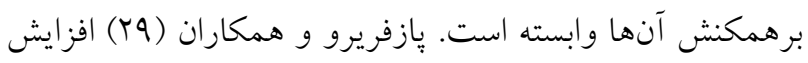

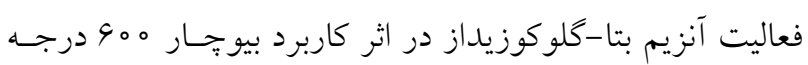

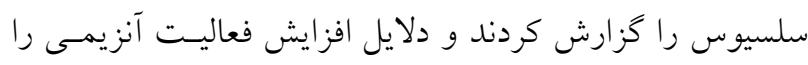

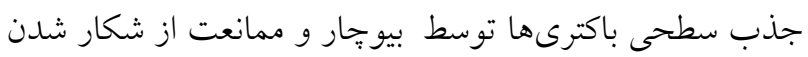

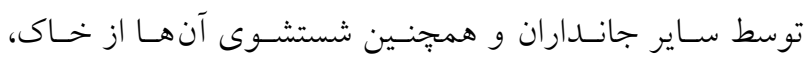
حفاظت باكترىها و قارجها در برابـر جـرا شـدن توسط سـاير

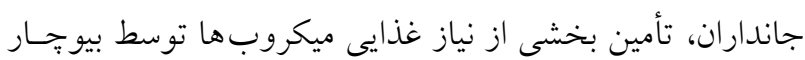

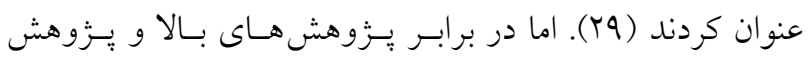




$$
\begin{aligned}
& \text { كلوكوزيداز را داشت كه مىتواند بهدليل مقدار كربن آلى زيـاد }
\end{aligned}
$$

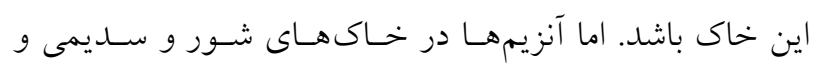

$$
\begin{aligned}
& \text { آهكى فعاليت كمترى داشتند و در خاك سديمى شديد كمترين } \\
& \text { فعاليـت آنـزيمهــاى فسفومونواسـتراز اسـيدى، بروتئساز و بتــا- } \\
& \text { كلوكوزيداز مشاهده شد. كاربرد يودر هستـه خرمـا و بيوجــار و }
\end{aligned}
$$

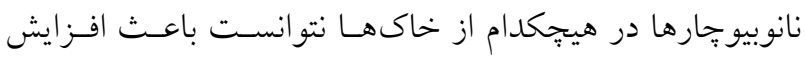

$$
\begin{aligned}
& \text { فعاليت آنزيمها شود و بـاوجود اينكـهـ افـزودن بيوجهـار و وبـودر }
\end{aligned}
$$

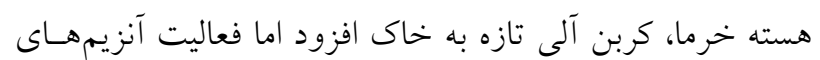

$$
\begin{aligned}
& \text { اندازهذيرى شده افزايش نيافته و حتى كاهش يافت. بهنظر مسى- }
\end{aligned}
$$

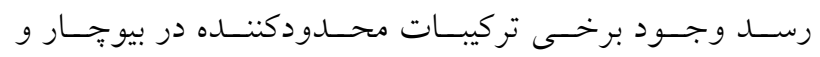

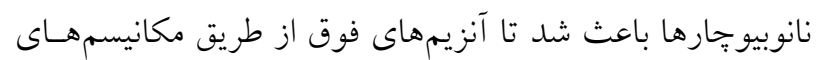

$$
\begin{aligned}
& \text { مختلفى مانند جذب و يا كلات شدن و بسىتحـرك شـدن مهـار } \\
& \text { شده و فعاليت مناسب نداشته باشند. در اين بزوهش خاكهـايى } \\
& \text { با مشكل شور -سديمى شديد استفاده شد. بهنظر مىرسـد زيـاد } \\
& \text { بودن مشكل شورى و سديمى خاكها باعث شده تا اثر تيمارهـا } \\
& \text { بر ويزگى هاى خاكها تحت تأثير قرار كيـرد. بيشـنهاد مسىشـود }
\end{aligned}
$$

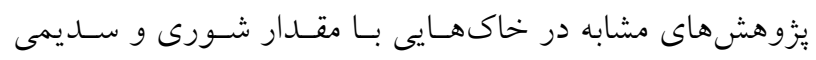

$$
\begin{aligned}
& \text { بودن كمتر نيز انجام كيرد. }
\end{aligned}
$$

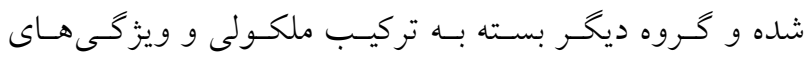
تاخوردگى و جّخونكى جذب سطحى به بيو جار كاهش فعاليـت نشان مىدهند (YN). انتظار مىرود كه تركيبهاى قابـل حـل در آب مانند اسيدها، الكلها، آلدهيدها، كتونها و قندها كه توسـط ريزجانداران خاك بهآسانى متابوليزه مسىشـوند، آتــار مثبتى بـر ريزجانداران خاك داشته باشند درحالى كه ممكن است حضـور

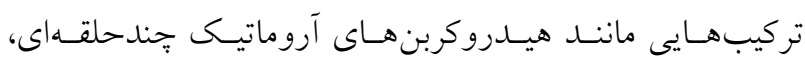
زايلنـوز، اكـرولين، فرمالدهيـد، كرسـولز و سـاير تركيـبـهـاى كربو كسيلى سمّى كه بسته به شرايط گرماكافت ممكــن اسـت از طريق بيوجار به خاك افزوده شوند، داراى آثـار ضـدباكتريايى و ضدقارجى باشند (ه). (ه).

$$
\text { نتيجه كيرى }
$$

در اين ثيزوهش فعاليت جهار نـوع آنـزيم در اثـر كـاربرد يـودر

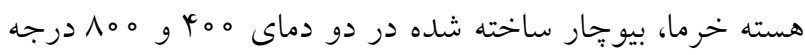
سلسيوس و نانوبيو جار آنها و نانوذره هيدروترمال بر خاكهاى با ويز گیىهاى مختلف در بخشهـاى ريزوسـفر و غيرريزوسـفر كياه كل كاوزبان ارويايى بررسى شد. خاك اسـيدى بـيش تـرين

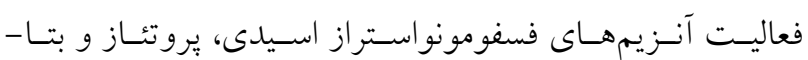

\section{منابع مورد استفاده}

1. Aleksieva, P., Spasova, D., Radoerska, S., 2003. Acid phosphatase distribution and localization in the fungus humicola lutea. Zeitschrift fur Naturforschung C 58(3): 239-243.

2. Aliasgharzad, N., 2010. Methods in Soil Biology. Tabriz University Press. (Translated in Persian)

3. Aseri, G.K., Neelam J., Tarafdar, J.C., 2009. Hydrolysis of organic phosphate forms by phosphatases and phytase producing fungi of arid and semi-arid soils of India. American-Eurasian Journal of Agricultural and Environmental Science 5(4): 564-570.

4. Awad, Y.M., Blagodatskaya, E., Ok, Y.S., Kuzyakov, Y., 2012. Effects of polyacrylamide, biopolymer and biochar on decomposition of soil organic matter and plant residues as determined by ${ }^{14} \mathrm{C}$ and enzyme activities. European Journal of Soil Biology 48: 1-10.

5. Azimzadeh, Y., Najafi, N., 2017. Effects of biochar on soil physical, chemical, and biological properties. Journal of Land Management 4(2): 161-173. (in Persian with English abstract)

6. Bailey, V.L., Fansler, S.J., Smith, J.L., Bolton, H., 2011. Reconciling apparent variability in effects of biochar amendment on soil enzyme activities by assay optimization. Soil Biology and Biochemistry 43: 296-301

7. Balík J., Pavlíková D., Vaněk V., 2007. The influence of long-term sewage sludge application on the activity of phosphatases in the rhizosphere of plants. Plant, Soil and Environment 53: 375-381.

8. Bamminger, C., Marschner, B., Juschke, E., 2014. An incubation study on the stability and biological effects of pyrogenic and hydrothermal biochar in two soils. European Journal of Soil Science 65: 72-82.

9. Burns, R.G., DeForest, J.L., Marxsen, J., Sinsabaugh, R.L., Stromberger, M.E., Wallenstein, M.D., Weintraub, M.N., Zoppini, A., 2013. Soil enzymes in a changing environment: current knowledge and future directions. Soil Biology and Biochemistry 58: 216-234. 
10. Chen, H., 2003. Phosphatase activity and $\mathrm{P}$ fractions in soils of an 18-year-old Chinese fir (Cunninghamia lanceolata) plantation. Forest Ecology and Management 178: 301-310.

11. Dick, R.P., Sandor, J.A., Eash, N.S., 1994. Soil enzyme activities after 1500 years of terrace agriculture in the colca Vally, Peru. Agriculture, Ecosystems \& Environment 50: 123-131.

12. Fereidooni, M., Raiesi, F., Falah, S., 2011. The trend of $\mathrm{CO}_{2}$ production and alteration of microbial biomass carbon in soils treated with urea fertilizer and broiler litter. Journal of Water and Soil Science 14(54): 97-110. (in Persian with English abstract)

13. Galvez, A., Siniccoa, T., Cayuelac, M.L., Mingoranceb, M.D., Fornasiera, F., Mondinia, C., 2012. Short term effects of bioenergy byproducts on soil $\mathrm{C}$ and $\mathrm{N}$ dynamics, nutrient availability and biochemical properties. Agriculture, Ecosystems \& Environment 160: 3-14.

14. Gul, S., Whalen, J.K., Thomas, B.W., Sachdeva, V., Deng, H., 2015. Physicochemical properties and microbial responses in biochar-amended soils: mechanisms and future directions. Agriculture, Ecosystems \& Environment 206: 46-59.

15. Jin, Y., Liang, X., He, M., Liu, Y., Tian, G., and Shi, J., 2016. Manure biochar influence upon soil properties, phosphorus distribution and phosphatase activities: a microcosm incubation study. Chemosphere 142: 128-135.

16. Juma, N.G., Tabatabai, M.A., 1977. Effects of trace elements on phosphatase activity in soils. Soil Science Society of America Journal 41: 343-346.

17. Ladd, J.N., Butler, J.H.A., 1972. Short term assay of soil proteolytic enzyme activities using proteins and dipeptide derivatives as substrates. Soil Biology and Biochemistry 4: 19-30.

18. Leirós, M.C., Trasar-Cepeda, C., Seoane, S., Gil-Sotres, F., 2000. Biochemical properties of acid soils under oak vegetation (Atlantic oakwood) in an area of the European temperate-humid zone (Galicia, NW Spain): general parameters. Soil Biology and Biochemistry 32: 733-745.

19. Malcolm, R.E., 1983. Assessment of phosphatase activity in soil. Soil Biology and Biochemistry 15: 403-408.

20. Masto, R.E., Kumar, S., Rout, T.K., Sarkar, P., George, J., Ram, L.C., 2013. Biochar from water hyacinth (Eichornia crassipes) and its impact on soil biological activity. Catena 111: 64-71.

21. McGill, W.B., Cole, C.V., 1981. Comparative aspects of cycling of organic C, N, S and P through soil organic matter. Geoderma 26: 267-286.

22. Mierzwa-Hersztek, M., Gondek, K., Baran, A., 2016. Effect of poultry litter biochar on soil enzymatic activity, ecotoxicity and plant growth. Applied Soil Ecology 105: 144-150.

23. Momeni, A., 2010. Geographical distribution of salinity in Iran's soil resources. The Iranian Journal of Soil Research 24: 203-216. (in Persian)

24. Nannipieri, P., Giagnoni, L., Renella, G., Puglisi, E., Ceccanti, B., Masciandaro, G., Fornasier, F., Moscatelli, M.C., Marinari, S., 2012. Soil enzymology: classical and molecular approaches. Biology and Fertility of Soils 48: $743-762$.

25. Nuruzzaman, M., Lambers, H., Bolland, M.D.A., 2006. Distribution of carboxylates ad acid phosphatase and depletion of different phosphorus fractions in the rhizosphere of a cereal and three grain legumes. Plant and Soil 281: $109-120$.

26. Oleszczuk, P., Josko, I., Futa, B., Pasieczna-Patkowska, S., Palys, E., Kraska, P., 2014. Effect of pesticides on microorganisms, enzymatic activity and plant in biochar-amended soil. Geoderma 214-215: 10-18

27. Pathak, H., Rao, D.L.N., 1998. Carbon and nitrogen mineralization from added organic matter in saline and alkali soils. Soil Biology and Biochemistry 30: 695-702.

28. Paz-Ferreiro, J., Fu, S., Mendez, A., Gasco, G., 2014. Interactive effects of biochar and the earthworm (Pontoscolex corethrurus) on plant productivity and soil enzyme activities. Journal of Soils and Sediments 14: 483-494.

29. Paz-Ferreiro, J., Gasco, G., Gutierrez, B., Mendez, A., 2012. Soil biochemical activities and the geometric mean of enzyme activities after application of sewage sludge and sewage sludge biochar to soil. Biology and Fertility of Soils 48: 511-517.

30. Safari, S.A., Sharifi, Z., 2007. Changes of available phosphorus and phosphatase activity in the rhizosphere of some field and vegetation crops in the fast growth stage. Journal of Applied Sciences and Environmental Management 11: $113-118$.

31. Sohi, S.P., Krull, E., Lopez-Capel, E., Bol, R., 2010. A review of biochar and its use and function in soil. Advances in Agronomy 105: 47-82.

32. Strobl, W., Traumuller, M., 1996. $\beta$-Glucosidase activity. In: Schinner, F., Öhlinger, R., Kandeler, E., Margesin, R., (Eds.), Methods in Soil Biology. Springer-Verlag, Berlin Heidelberg. pp: 198-200.

33. Tarafdar J.C., Jungk A., 1987. Phosphatase activity in the rhizosphere and its relation to the depletion of soil organic phosphorus. Biology and Fertility of Soils 3: 199-204.

34. Thomson, B., Robson, A.D., Abbort, L.K., 1986. Effects of phosphorus on the formation of mycorrhizas by Gigaspora and Glomus fasciculatum in relation to root carbohydrates. New Phytologist 103: 751-763. 
35. Toloei Darab, A., 2016. Activity of urease, acidic and alkaline phosphatases enzymes in soil and biochar in pot culture of corn under water stress. MSc Thesis, Faculty of Agriculture, University of Tabriz, Iran.

36. Turpault, MP., 2006. Sampling of rhizosphere soil for physico-chemical and mineralogical analyses by physical separation based on dyeing and shaking. In: Luster, J., Finlay, R., (Eds.), Handbook of Methods Used in Rhizosphere Research. Swiss Federal Research Institute WSL, pp. 196-197.

37. Vaccari, F., Baronti, S., Lugato, E., Genesio, L., Castaldi, S., Fornasier, F., Miglietta, F., 2011. Biochar as a strategy to sequester carbon and increase yield in durum wheat. European Journal of Agronomy 34(4): 231-238.

38. Wang, X., Song, D., Liang, G., Zhang, Q., Ai, C., Zhou, W., 2015. Maize biochar addition rate influences soil enzyme activity and microbial community composition in a fluvio-aquic soil. Applied Soil Ecology 96: 265-272.

39. Watzinger, A., Feichtmair, S., Kitzler, B., Zehetner, F., Kloss, S., Wimmer, B., Boltenstern, S.Z., Soja, G., 2014. Soil microbial communities responded to biochar application temperate soils and slowly metabolized ${ }^{13} \mathrm{C}$-labelled biochar as revealed by ${ }^{13} \mathrm{C}$ PLFA analysis: results from a short-term incubation and pot experiment. European Journal of Soil Science 65: 40-51.

40. Wu, F., Jia, Z., Wang, S.S., Chang, X., Startse, A., 2013. Contrasting effects of wheat straw and its biochar on greenhouse gas emissions and enzyme activities in a Chernozemic soil. Biology and Fertility of Soils 49: 555-565. 


\title{
Effect of Date Kernel Biochars on Enzymatic Activity in Rhizosphere and Non-rhizosphere Soils of European Borage (Borago officinalis L.)
}

\author{
A. Abbasian ${ }^{1}$ and M. Sheklabadi*
}

(Received: 19 March 2021; Accepted: 21 June 2021)

\begin{abstract}
The aim of this study was to investigate the effect of date kernel biochar and nano-biochar on enzymatic activities of rhizosphere and non-rhizosphere environment of European borage. The date kernel was converted to biochar at 400 and $800{ }^{\circ} \mathrm{C}$ pyrolysis temperatures and mixed with different soils. Four soils with different characteristics including acidic, calcareous, saline-sodic and saline-highly sodic were selected. Biochars were then converted to nano-size materials using the rolling ball method. Also nanoparticles were extracted from date kernel powder by hydrothermal method. The obtained biochars were mixed with soil and transferred to greenhouse pots. European borage was planted and harvested after 60 days. Rhizospheric and non-rhizospheric soils were collected and the activity of acidic and alkaline-phosphomonoesterase, protease and $\beta$-glucosidase enzymes were measured. The highest and lowest activities of acid-phosphomonoesterase, protease and $\beta$-glucosidase enzymes were found in the acidic and saline-highly sodic soils, respectively. However, the highest alkaline-phosphomonoesterase activity was observed in the saline-highly sodic soil. The activity of enzymes in the rhizosphere soil was greater than in the non-rhizosphere soil. The highest activities of enzymes were found in the control and were reduced by using biochar, nano-biochar and nanoparticle biochars. The conversion of biochar to nano-biochar could not increase the activity of enzymes in the soil.
\end{abstract}

Keywords: Biochar, Calcareous soil, Enzyme activity, Nano-biochar, Nano-particle, Saline-sodic soil.

Background and Objective: Soil enzymes are important for catalyzing the vital processes of soil microorganisms, decomposition of organic residues, element cycles, organic matter formation and soil structure. A few investigations have been performed on the effect of applying biochar or nano-biochar in saline or sodic soils. The aim of this study was to investigate the effect of using date kernel biochar and nano-biochar produced at two different temperatures in salt- and sodium-affected soils on the activity of some soil enzymes in the rhizosphere of European borage species.

Methods: Four topsoils with different physical and chemical properties were collected: calcareous soil with agricultural use $\left(52.5 \%\right.$ of CCE), saline-sodic soil with agricultural use (36.65 dS m $\left.\mathrm{m}^{-1}\right)$, saline-highly sodic soil (taken from a bare land with EC of $7.51 \mathrm{dS} \mathrm{m}^{-1}$, and SAR of 229.2), and acidic soil $(\mathrm{pH}=4.37$ ) sampled from a tea garden. Date kernel powder was used to produce biochar at two different temperatures (400 and $800{ }^{\circ} \mathrm{C}$ ) in oxygen-free conditions. The biochar prepared at 400 and $800{ }^{\circ} \mathrm{C}$ were converted to nano-biochar

1- Department of Soil Science, Faculty of Agriculture, Bu-Ali Sina University

* Corresponding Author, Email: sheklabadi@basu.ac.ir 
by the ball mill method and sieved with a nano-sized mesh. In addition, nanoparticles were prepared from date kernel powder using hydrothermal method. Soils were mixed with $5 \%$ by weight of the treatments, and transferred to $10 \mathrm{~kg}$ pots with 3 replicates. For each soil, a control treatment receiving no biochar was used. A variety of European borage (Borago officinalis L) was planted in pots and after 60 days harvested. Rhizosphere soils were separated from non-rhizosphere soils for each pot. In both rhizosphere and nonrhizosphere soils, the activities of $\beta$-glucosidase, acid-phosphomonoesterase, alkaline-phosphomonoesterase and protease were measured by standard methods. The experiment was analyzed as a factorial with a completely randomized design and three replications.

Results: The highest and lowest activities of acid-phosphomonoesterase, protease and $\beta$-glucosidase were observed in the acidic and saline-highly sodic soils, respectively. A significant difference was observed between the rhizosphere and non-rhizosphere environments due to the effect of root and microorganism's activity and their secretions. However, the activity of acid-phosphomonoesterase and $\beta$-glucosidase in the rhizosphere of saline-highly sodic soil was not significantly increased owing to depressed plant growth and poor root development. The activity of acid-phosphomonoesterase, protease and $\beta$-glucosidase were the highest in the control and were significantly decreased by applying biochar and nano-biochar in both rhizosphere and non-rhizosphere soils. Application of biochar and nano-biochar to all soils significantly reduced the activity of $\beta$-glucosidase by $40-59 \%$ compared to the control. However, the activity of protease enzyme in the saline-highly sodic soil decreased sharply even after receiving biochar. In the rhizosphere, the protease activity in all soils was significantly higher than in the non-rhizosphere soils. Applying of biochars to the acidic and saline-highly sodic soils caused significant decrease in protease activity by 50 to $75 \%$. The highest and lowest activities of alkaline-phosphomonoesterase were observed in the saline-highly sodic and acidic soils. The activity of alkaline-phosphomonoesterase in acidic soil was about $30 \%$ of its activity in the saline-highly sodic soil and 50 to $70 \%$ of its activity in the calcareous and saline-sodic soils. Due to the alkaline nature of the enzyme, the observed results were expected. The activity of this enzyme in the rhizosphere part of all soils was significantly higher than the non-rhizosphere soil. The application of biochar and nano-biochar and also nano-particles caused a significant decrease in the activity of alkalinephosphomonoesterase in all four soils. The negative effect of soil salinity and phosphorus concentration can be related to the activity of these enzymes in soils. Phosphatase enzyme increases soil mineral phosphorus whereby, it reduces soil phosphatase activity (3). Bailey et al. (1) showed that the effects of biochar on soil enzymatic activity depend on soil type, biochar type and their interactions. Many studies have shown that the application of biochar in soil can stimulate and increase the activity of soil enzymes (2). The biochar may contain substances that limits the activity, immobilizes or removes the enzymes from the soil.

Conclusions: Acidic soil had the highest activity of acid-phosphomonoesterase, protease and $\beta$-glucosidase enzymes, which could be attributed to high soil organic matter. Application of date kernel powder, biochar and nano-biochar did not increase the activity of enzymes studied and despite the addition of fresh organic carbon to the soil, no proper enzymatic response was observed. The composition of applied biochar and nano-biochar may cause inhibition of enzymes by various mechanisms.

\section{References:}

1. Bailey, V.L., Fansler, S.J., Smith, J.L., Bolton Jr, H., 2010. Reconciling apparent variability in effects of biochar amendment on soil enzyme activities by assay optimization. Soil Biology and Biochemistry 43: 296-301.

2. Paz-Ferreiro, J., Fu, S., Mendez, A., Gasco, G., 2014. Interactive effects of biochar and the earthworm (Pontoscolex corethrurus) on plant productivity and soil enzyme activities. Journal of Soils and Sediments 14: 483-494.

3. Saha, S., Mina, B.L., Gopinath, K.A., Kundu, S., Gupta, H.S., 2008. Relative changes in phosphatase activities as influenced by source and application rate of organic composts in field crops. Bioresource Technology 99: 1750-1757. 